\title{
Diversity of Viruses Infecting Eukaryotic Algae
}

\author{
Steven M. Short ${ }^{1,2 *}$, Michael A. Staniewski ${ }^{1}$, Yuri V. Chaban², \\ Andrew M. Long ${ }^{1}$, and Donglin Wang ${ }^{1}$

\begin{abstract}
${ }^{1}$ Department of Ecology and Evolutionary Biology, University of Toronto, Toronto, ON, Canada.
${ }^{2}$ Department of Biology, University of Toronto Mississauga, Mississauga, ON, Canada.

*Correspondence: steven.short@utoronto.ca
\end{abstract}

https://doi.org/10.21775/cimb.039.029

\begin{abstract}
Algae are photosynthetic organisms that drive aquatic ecosystems, e.g. fuelling food webs or forming harmful blooms. The discovery of viruses that infect eukaryotic algae has raised many questions about their influence on aquatic primary production and their role in algal ecology and evolution. Although the full extent of algal virus diversity is still being discovered, this review summarizes current knowledge of this topic. Where possible, formal taxonomic classifications are referenced from the International Committee on Taxonomy of Viruses (ICTV); since the pace of virus discovery has far surpassed the rate of formal classification, however, numerous unclassified viruses are discussed along with their classified relatives. In total, we recognized 61 distinct algal virus taxa with highly variable morphologies that include dsDNA, ssDNA, dsRNA, and ssRNA genomes ranging from approximately 4.4 to $560 \mathrm{~kb}$, with virion sizes from approximately 20 to $210 \mathrm{~nm}$ in diameter. These viruses infect a broad range of algae and, although there are a few exceptions, they are generally lytic and highly species or strain specific. Dedicated research efforts have led to the appreciation of algal viruses as diverse, dynamic, and ecologically important members of the biosphere, and future investigations will continue to reveal the full extent of their diversity and impact.
\end{abstract}

\section{Introduction}

Algae are the engines of aquatic ecosystems that convert inorganic matter into organic matter and fuel aquatic food webs. Their growth influences the productivity of aquatic environments, and also environmental quality by either supporting or impeding beneficial human use, e.g. by sustaining fisheries, or forming nuisance blooms. A few decades ago, scientists discovered that viruses infecting eukaryotic algae are present in nearly all aquatic environments, and that most of these pathogens are both speciesspecific and cause the lysis, or death, of their hosts. As an aside, throughout this review we will use the term 'algae' specifically to refer to eukaryotic algae; in some discussions of aquatic primary production cyanobacteria are also included under the umbrella term algae, such as in the first two sentences of this paragraph, but here we are focusing only on eukaryotes. Discovery of ubiquitous algal viruses in aquatic environments raised many questions about the influence of viruses on aquatic primary production and their role in algal ecology and evolution, and spurred the development of algal virus ecology as a research field unto itself. Work on this topic has taught us much about the importance of algal viruses, and over the years numerous reviews have summarized this work (Brussaard, 2004; Brussaard and Martínez Martínez, 2008; Dunigan et al., 2006; Kang et al., 2005; Nagasaki, 2008; Short, 2012; Suttle, 2000; Van Etten et al., 2002; Van Etten and Meints, 1999; Wilson et al., 2009; Yamada et al., 
2006). Yet we still lack a deep understanding of algal virus diversity and the range of algae that are susceptible to viral infections.

At this stage of algal virus research, more than 40 years after the first virus was isolated from an infected eukaryotic alga (Mayer and Taylor, 1979), observer effects are rife so it is challenging to discern if any observations reflect natural patterns of diversity. For example, viral metagenomes and PCR-based diversity surveys (Hyman and Abedon, 2018) of large dsDNA algal viruses have been dominated by a single group within the Phycodnaviridae, the Prasinoviruses (Clasen and Suttle, 2009; Hingamp et al., 2013; Short and Short, 2008; Zhong and Jacquet, 2014). Moreover, almost all isolated viruses that infect diatoms, an algal group with an enormous role in global biogeochemistry, have been isolated from species of Chaetoceros, and the only viruses of macrophytic algae infect the reproductive spores of certain brown algae within the order Ectocarpales. These observations could be interpreted to suggest that these types of algae are particularly permissive hosts for viral parasites, or that most other algae are resistant to viral infections. In reality, it is more likely that surveys of virus diversity are far from complete, and ongoing isolation and genomic efforts will reveal even greater diversity than is currently known; patterns of diversity inferred from current literature in other words likely do not capture fully the patterns of nature.

Given the caveats that it is not clear what should be considered a virus 'species', and most algal viruses are not yet formally classified by the International Committee on Taxonomy of Viruses (ICTV), we have compiled an up-to-date list of all algal virus 'species' reported in the literature (Table 10.1). In this list we have included viruses that can be considered distinct because of hosts they infect, or because of other viral characteristics, or both. In some cases viruses that might represent distinct strains or species are grouped into a single line in the table. For example, Table 10.1 lists $\mathrm{MpV}$ as a single virus type infecting the marine prasinophyte Micromonas pusilla, but seven $\mathrm{MpV}$ viruses were actually described that fell into four groups based on molecular weights of major proteins (Cottrell and Suttle, 1991). A similar situation exists for the chloroviruses such as those that infect Chlorella NC64a (Chlorella variabilis); these cases will be discussed in more detail in the sections that follow.
In total, 61 viruses are listed in Table 10.1 infecting algal species belonging to six phyla and ten classes. Because virus systematics is a work in progress and discovery is ongoing, this number however merely represents the minimum number of unique viruses isolated from eukaryotic algae. It is true that these viruses have been isolated from diverse algal hosts, but the number of isolates and the diversity of their hosts pales in comparison to the estimated 64,500 species belonging to 14 phyla and 51 classes of eukaryotic algae (Guiry, 2012). It is reasonable to think that most, if not all algal species are hosts to one or more types of viruses, but of course even that notion is purely speculative.

Despite the obvious gaps in our knowledge of algal virus diversity, ongoing isolation efforts over the past few decades have continuously revealed novel algal viruses. Indeed, the rate of algal virus discovery, inferred from literature reports, has remained relatively constant since the 1990s and can be expected to continue as long as there is interest in how these parasites influence or possibly control aquatic food webs (Fig. 10.1). It is clear that there is much to be learned about the diversity of these globally important algal parasites, and we are far from knowing the extent of algal virus diversity.

No matter how incomplete our current knowledge, since their first discovery an impressive volume of information about algal viruses has been obtained and the field has expanded far beyond the early days of research when the only known algal viruses were dsDNA viruses assigned to the order Phycodnaviridae. Currently, dsDNA, ssDNA, dsRNA, and ssRNA viruses have been isolated from algae, and some isolates remain uncharacterized with respect to their genome type, or the nature of some genomes is speculative (Fig. 10.2). Thus, while much needs to be learned, enough is known about algal viruses to warrant the following review. In line with the classical Baltimore virus classification scheme (Baltimore, 1971) (Hyman and Abedon, 2018), we have organized the sections of this review by genome type. Since the majority of known algal viruses are dsDNA viruses, that section is split into subsections describing each recognized genera of dsDNA algal viruses followed by a brief note identifying the many dsDNA viruses not formally classified by the ICTV; many of these unclassified viruses are closely related to or are even widely accepted by researchers as species of recognized 
Table 10.1 Reports describing isolations and/or preliminary characterizations of algal viruses

\begin{tabular}{|c|c|c|c|}
\hline Virus & Host(s) & Host phylum/class & References \\
\hline $\mathrm{AaV}(\mathrm{BtV})$ & Aureococcus anophagefferens & Ochrophyta/Pelagophyceae & Milligan and Cosper (1994) \\
\hline AglaRNAV & Asterionellopsis glacialis & Bacillariophyta/Bacillariophyceae & Tomaru et al. (2012) \\
\hline ATCV & Chlorella heliozoae (SAG 3.83) & Chlorophyta/Trebouxiophyceae & Bubeck and Pfitzner (2005) \\
\hline BpV & Bathycoccus sp. & Chlorophyta/Prasinophyceae & Bellec et al. (2009) \\
\hline $\mathrm{CbV}$ & $\begin{array}{l}\text { Chrysochromulina brevifilum, C. } \\
\text { strobilus }\end{array}$ & Haptophyta/Coccolithophyceae & Suttle and Chan (1995) \\
\hline CdebDNAV & Chaetoceros debilis & Bacillariophyta/Mediophyceae & Tomaru et al. (2008b) \\
\hline $\mathrm{CeV}$ & Chrysochromulina ericina & Haptophyta/Coccolithophyceae & Sandaa et al. (2001) \\
\hline ClorDNAV & Chaetoceros lorenzianus & Bacillariophyta/Mediophyceae & Tomaru et al. (2011b) \\
\hline $\mathrm{CpV}$ & Chrysochromulina parva & Haptophyta/Coccolithophyceae & Mirza et al. (2015) \\
\hline CsetDNAV & Chaetoceros setoensis & Bacillariophyta/Mediophyceae & Tomaru et al. (2013b) \\
\hline CsfrRNAV & Chaetoceros socialis f. radians & Bacillariophyta/Mediophyceae & Tomaru et al. (2009b) \\
\hline $\begin{array}{l}\text { CsalDNAV } \\
\text { (CsNIV) }\end{array}$ & Chaetoceros salsugineum & Bacillariophyta/Mediophyceae & Nagasaki et al. (2005c) \\
\hline Csp03RNAV & Chaetoceros sp. & Bacillariophyta/Mediophyceae & Tomaru et al. (2013a) \\
\hline Csp05DNAV & Chaetoceros sp. & Bacillariophyta/Mediophyceae & Toyoda et al. (2012) \\
\hline Csp07DNAV & Chaetoceros sp. & Bacillariophyta/Mediophyceae & Kimura and Tomaru (2013) \\
\hline CspNIV & Chaetoceros cf. gracilis & Bacillariophyta/Mediophyceae & Bettarel et al. (2005) \\
\hline CtenDNAV & Chaetoceros tenuissimus & Bacillariophyta/Mediophyceae & Tomaru et al. (2011a) \\
\hline $\begin{array}{l}\text { CtenDNAV } \\
\text { type II }\end{array}$ & Chaetoceros tenuissimus & Bacillariophyta/Mediophyceae & Kimura and Tomarua (2015) \\
\hline CtenRNAV & Chaetoceros tenuissimus & Bacillariophyta/Mediophyceae & Shirai et al. (2008) \\
\hline $\begin{array}{l}\text { CtenRNAV } \\
\text { type II }\end{array}$ & $\begin{array}{l}\text { Chaetoceros sp., C. tenuissimus, } \\
\text { C. setoensis, C. socialis } \mathrm{f} . \\
\text { radians }\end{array}$ & Bacillariophyta/Mediophyceae & Kimura and Tomarua (2015) \\
\hline CVM & $\begin{array}{l}\text { Micractinium conductrix } \\
\text { (Chlorella Pbi) }\end{array}$ & Chlorophyta/Trebouxiophyceae & $\begin{array}{l}\text { Reisser et al. (1986), Reisser } \\
\text { et al. (1988) }\end{array}$ \\
\hline CwNIV & Chaetoceros cf. wighamii & Bacillariophyta/Mediophyceae & Eissler et al. (2009) \\
\hline EfasV & Ectocarpus fasciculatus & Ochrophyta/Phaeophyceae & $\begin{array}{l}\text { Müller et al. (1996), Kapp et } \\
\text { al. (1997) }\end{array}$ \\
\hline EhV & Emiliania huxleyi & Haptophyta/Coccolithophyceae & Castberg et al. (2002) \\
\hline EsV & $\begin{array}{l}\text { Ectocarpus siliculosus, } \\
\text { Kuckuckia kylinii }\end{array}$ & Ochrophyta/Phaeophyceae & $\begin{array}{l}\text { Müller et al. (1992), Müller } \\
\text { (1996), Lanka et al. (1993) }\end{array}$ \\
\hline FirrV & Feldmannia irregularis & Ochrophyta/Phaeophyceae & Kapp et al. (1997) \\
\hline FlexV & Feldmannia simplex & Ochrophyta/Phaeophyceae & Friess-klebl et al. (1994) \\
\hline FsV & Feldmannia sp. & Ochrophyta/Phaeophyceae & Henry and Meints (1992) \\
\hline HaNIV & Heterosigma akashiwo & Ochrophyta/Raphidophyceae & Lawrence et al. (2001) \\
\hline HaRNAV & Heterosigma akashiwo & Ochrophyta/Raphidophyceae & $\begin{array}{l}\text { Nagasaki and Yamaguchi } \\
\text { (1997) }\end{array}$ \\
\hline $\mathrm{HaV}$ & Heterosigma akashiwo & Ochrophyta/Raphidophyceae & Tai et al. (2003) \\
\hline HcDNAV & Heterocapsa circularisquama & Miozoa/Dinophyceae & Tarutani et al. (2001) \\
\hline HcRNAV & Heterocapsa circularisquama & Miozoa/Dinophyceae & Tomaru et al. (2004a) \\
\hline $\mathrm{HcV}$ & Heterocapsa circularisquama & Miozoa/Dinophyceae & Tarutani et al. (2001) \\
\hline HeV RF02 & $\begin{array}{l}\text { Haptolina ericina, Prymnesium } \\
\text { kappa }\end{array}$ & Haptophyta/Coccolithophyceae & Johannessen et al. (2015) \\
\hline
\end{tabular}


Short et al.

Table 10.1 Continued

\begin{tabular}{|c|c|c|c|}
\hline Virus & Host(s) & Host phylum/class & References \\
\hline HincV & Hincksia hinckiae & Ochrophyta/Phaeophyceae & Kapp et al. (1997) \\
\hline HpygDNAV & Heterocapsa pygmaea & Miozoa/Dinophyceae & Kim et al. (2012) \\
\hline HVCV & $\begin{array}{l}\text { Chlorella-like endosymbiont of } \\
\text { Hydra viridis }\end{array}$ & Chlorophyta/Trebouxiophyceae & Van Etten et al. (1981) \\
\hline MclaV & Myriotrichia clavaeformis & Ochrophyta/Phaeophyceae & Kapp et al. (1997) \\
\hline MiV & Micromonas sp. & Chlorophyta/Prasinophyceae & Bellec et al. (2009) \\
\hline MpRV & Micromonas pusilla & Chlorophyta/Prasinophyceae & Brussaard et al. (2004a) \\
\hline $\mathrm{MpV}$ & Micromonas pusilla & Chlorophyta/Prasinophyceae & $\begin{array}{l}\text { Mayer and Taylor (1979), } \\
\text { Cottrell and Suttle (1991) }\end{array}$ \\
\hline MpVN1 & Micromonas pusilla & Chlorophyta/Prasinophyceae & Zingone et al. (2006) \\
\hline MpVN2 & Micromonas pusilla & Chlorophyta/Prasinophyceae & Zingone et al. (2006) \\
\hline Ols1 & Heterosigma akashiwo & Ochrophyta/Raphidophyceae & Lawrence et al. (2006) \\
\hline OtV & Ostreococcus sp. & Chlorophyta/Prasinophyceae & Bellec et al. (2009) \\
\hline PBCV & $\begin{array}{l}\text { Chlorella variabilis (Chlorella } \\
\text { NC64A) }\end{array}$ & Chlorophyta/Trebouxiophyceae & $\begin{array}{l}\text { Van Etten et al. (1982), Van } \\
\text { Etten et al. (1983) }\end{array}$ \\
\hline PgV Group I & Phaeocystis globosa & Haptophyta/Coccolithophyceae & $\begin{array}{l}\text { Brussaard et al. (2004b), } \\
\text { Baudoux and Brussaard } \\
\text { (2005) }\end{array}$ \\
\hline PgV Group II & Phaeocystis globosa & Haptophyta/Coccolithophyceae & $\begin{array}{l}\text { Brussaard et al. (2004b), } \\
\text { Baudoux and Brussaard } \\
\text { (2005) }\end{array}$ \\
\hline PgV-102P & Phaeocystis globosa & Haptophyta/Coccolithophyceae & Wilson et al. (2006) \\
\hline PkV RF01 & $\begin{array}{l}\text { Prymnesium kappa, Haptolina } \\
\text { ericina }\end{array}$ & Haptophyta/Coccolithophyceae & Johannessen et al. (2015) \\
\hline PkV RF02 & Prymnesium kappa & Haptophyta/Coccolithophyceae & Johannessen et al. (2015) \\
\hline PlitV & Pilayella littoralis & Ochrophyta/Phaeophyceae & Maier et al. (1998) \\
\hline PoV & Pyramimonas orientalis & Chlorophyta/Prasinophyceae & Sandaa et al. (2001) \\
\hline $\mathrm{PpV}$ & Phaeocystis pouchetii & Haptophyta/Coccolithophyceae & Jacobsen et al. (1996) \\
\hline $\begin{array}{l}\text { RsetRNAV } \\
\text { (RsRNAV) }\end{array}$ & Rhizosolenia setigera & $\begin{array}{l}\text { Bacillariophyta/ } \\
\text { Coscinodiscophyceae }\end{array}$ & Nagasaki et al. (2004) \\
\hline ScosV & Skeletonema costatum & Bacillariophyta/Mediophyceae & Kim et al. (2015a) \\
\hline SpalV & Stephanopyxis palmeriana & $\begin{array}{l}\text { Bacillariophyta/ } \\
\text { Coscinodiscophyceae }\end{array}$ & Kim et al. (2015b) \\
\hline TampV & Teleaulax amphioxeia & Cryptophyta/Cryptophyceae & Nagasaki et al. (2009) \\
\hline TnitDNAV & Thalassionema nitzschioides & Bacillariophyta/Bacillariophyceae & Tomaru et al. (2012) \\
\hline TsV-N1 & Tetraselmis striata & $\begin{array}{l}\text { Chlorophyta/ } \\
\text { Chlorodendrophyceae }\end{array}$ & Pagarete et al. (2015) \\
\hline
\end{tabular}

Algae were classified at the level of phylum and class according to information from AlgaeBase (http://algaebase. org/, accessed 26 May 2016).

genera, so these are discussed in corresponding sections on classified taxa. On the other hand, there are many unclassified dsDNA algal viruses that were presumed to be members of the Phycodnaviridae, but based on more recent evidence should not be included in this family. To respect the history of algal virus discovery, many of these cases will be discussed in sections on classified viruses, and a separate section on unclassified viruses will note exceptions and questions that remain in algal virus systematics.

It is probable that this accounting of known algal viruses is incomplete since it seems likely that novel viruses have been isolated but have not yet been 


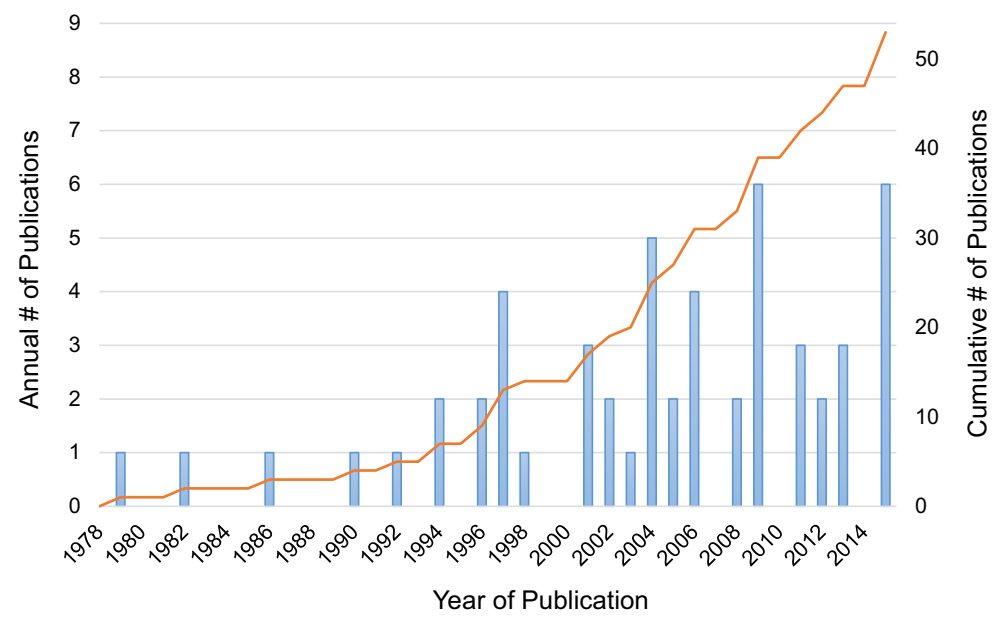

Figure 10.1 Annual and cumulative number of publications describing novel algal viruses. The blue bars show the individual number of publications each year, while the orange line represents the cumulative number of publications, as of year-end 2015. It should be noted that although most research articles focus on a single virus isolate, the number of viruses isolated does not directly correspond to the number of publications shown in this figure since some articles reported the isolation of several different viruses; the 61 virus isolates listed in Table 10.1 were reported in 51 unique publications. The publications that were used to generate this figure were the initial reports shown for each virus listed in Table 10.1.

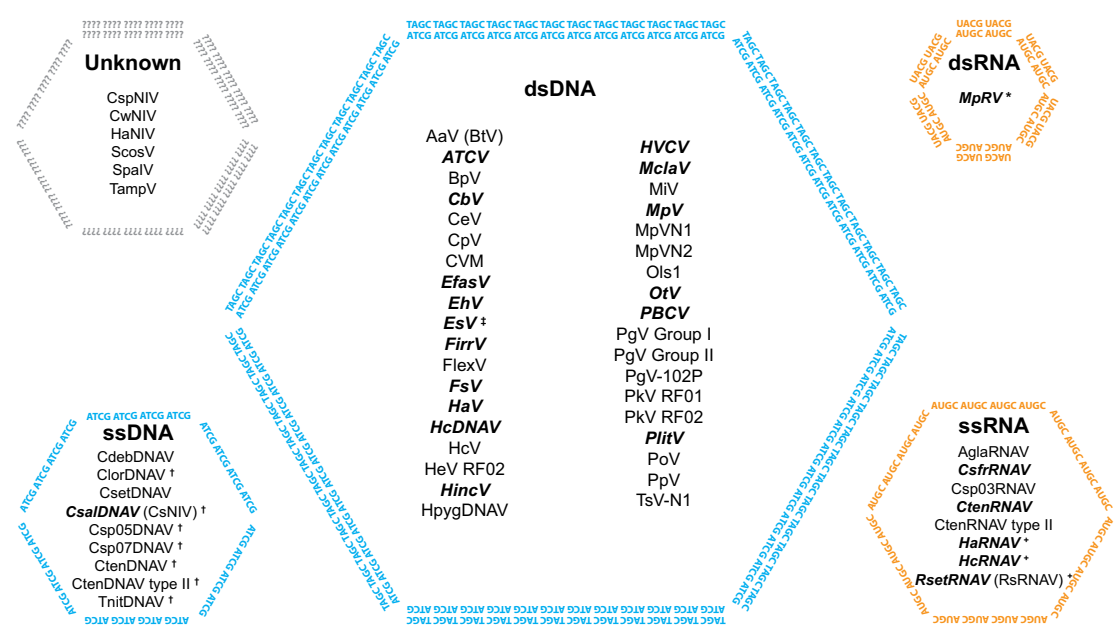

Figure 10.2 Isolated viruses infecting eukaryotic algae categorized by genome classification. Symbols that follow certain virus names highlight specific features of the viral genomes according to the following scheme: $\left(^{*}\right)$ segmented genome; (+) positive-sense RNA; $(\dagger)$ circular genome with partially double-stranded regions; $(\ddagger)$ circular genome with partially single-stranded regions. Virus names are simplified for brevity (e.g. MpV represents MpV-SPI and its closely related strains), and viruses that have been formally classified by the ICTV are highlighted with bold italic fonts. 
described in the literature. For example, in their article describing RNA viruses in tropical waters, Culley and co-authors (2014) included sequences from two novel viruses (CcloRNAV01 and 02) that infect pennate diatoms that, to our knowledge, have not been described elsewhere. Similarly, the genomic sequence of a virus that infects the Chlorophyte alga Dunaliella viridis has been determined and is available in GenBank (accession \# NC_023841), but no reports of this virus's isolation have been published. On that note, since molecular and genomic approaches have also been applied to the study of algal virus diversity, this review would not be complete without also drawing attention to these efforts that have provided major insights into the world of algal viruses.

\section{Diversity inferred from environmental nucleic acids}

\section{PCR studies}

Not long after viruses were observed to be abundant in marine environments (Bergh et al., 1989), researchers turned to cultivation-free molecular studies of environmental DNA (eDNA) to examine algal virus diversity (Hyman and Abedon, 2018). The first attempt to uncover the hidden diversity of algal viruses in natural communities was based on PCR amplification and sequence analysis of fragments of virus DNA polymerase genes (abbreviated as polB, or PolB when referring to the protein) from dsDNA algal viruses (Chen et al., 1996); at the time all known algal viruses were dsDNA viruses, classified as Phycodnaviridae. Moreover, development of universal, algal-virus-specific PCR primers (Chen and Suttle, 1995) demonstrated that virus DNA polymerase (i.e. polB) sequences were a robust taxonomic marker for phycodnaviruses and related dsDNA viruses (Chen and Suttle, 1996). Because several unknown phycodnaviruses were detected in Gulf of Mexico eDNA, this early research also highlighted the need for intensified work on algal virus diversity (Chen et al., 1996).

Subsequent virus diversity studies based on PCR amplification of algal virus (i.e. phycodnavirus) polB genes demonstrated that remarkably similar virus genes could be detected in different oceans (Short and Suttle, 2002), some virus genes were constantly present in some environments
(Short and Suttle, 2003), and freshwater environments are also inhabited by diverse algal viruses (Clasen and Suttle, 2009; Short et al., 2011; Short and Short, 2008; Zhong and Jacquet, 2014). These and other studies of phycodnavirus diversity based on PCR amplification with polB primers have led to the surprisingly consistent observation that polB libraries of natural water samples are dominated by sequences related to cultivated members of the genus Prasinovirus (e.g. Clasen and Suttle, 2009; Culley et al., 2009; Park et al., 2011; Short and Short, 2008; Zhong and Jacquet, 2014). Although the most parsimonious explanation for the preponderance of prasinovirus-like sequences is biased PCR methods, there is evidence from amplification-free metagenomic studies that the bias actually reflects the natural dominance of these types of viruses (Clasen and Suttle, 2009; Short, 2012). Whatever the case, it is apparent that algal-virus-specific polB primers are not truly universal because some cultivated algal viruses such as Emiliania huxleyi viruses cannot be amplified with this primer set.

Knowledge that the algal-virus-specific polB primers could not target viruses of the coccolithophore Emiliania huxleyi (EhVs) motivated development of PCR primers targeting their major capsid protein (MCP) (Schroeder et al., 2002). These primers were subsequently used to demonstrate that diverse populations of EhVs can be detected in the water column, but only a few genotypes dominate following termination of $E$. huxleyi blooms (Martínez Martínez et al., 2007). Moreover, some EhV genotypes (strains) seem cosmopolitan despite evidence for distinct $\mathrm{EhV}$ communities associated with specific localities (Rowe et al., 2011). Universal MCP primers that would target more than just coccolithoviruses were also developed with the aim to examine more broadly the diversity of viruses missed by the algalvirus-specific polB primers (Larsen et al., 2008).

Generally, amplification of eDNA with the algal virus MCP primers reveals greater diversity than can be detected with polB primers alone, and they are a complementary tool for examining algal virus diversity (Short, 2012). For example, studies of South Korean coastal waters (Park et al., 2011) and an embayment of Lake Ontario, Canada (Rozon and Short, 2013) using both MCP and polB primers demonstrated that the MCP primers readily amplified genes encoded by uncultured algal viruses that 
are not most closely related to known prasinoviruses. Instead, the MCP primers seem particularly effective for the amplification of genes from a clade of algal viruses that infect microalgae such as Phaeocystis globosa, Chrysochromulina ericina, or Pyramimonas orientalis. Currently, these unclassified algal viruses are considered members of the 'Megaviridae' group (Arslan et al., 2011; Santini et al., 2013) that are also known as 'extended Mimiviridae' (Fischer, 2016, Hyman and Abedon, 2018). The Megaviridae are, like their relatives in the Phycodnaviridae, part of a diverse group of dsDNA viruses termed nucleocytoplasmic large DNA viruses (NCLDVs) (Iyer et al., 2001; Iyer et al., 2006). The name 'Megavirales' has been proposed as a virus order encompassing the NCLDVs (Colson et al., 2013), but as of this writing the names Megaviridae and Megavirales have not yet been approved by the ICTV. Although their use is still debated among researchers studying algal viruses and their giant amoebae-infecting relatives (Fischer, 2016), these names are used widely in the literature. Hence, because of their wide use and the fact that these terms seem to have a legitimate taxonomic basis, Megavirales and NCLDVs, and Megaviridae and extended Mimiviridae will be used interchangeably here. Most recently, Moniruzzaman et al. (2016) developed an MCP primer set that specifically targets algae-infecting Megaviridae and monitored the diversity of this group over the course of a bloom of the brown tide causing alga Aureococcus anophagefferens. Hundreds of unique amplicons were observed that clustered into 145 OTUs (operational taxonomic units) at $97 \%$ nucleotide identity highlighting the huge but previously unobserved diversity of megaviruses. Community analysis of the sequence data highlighted the role of these viruses in the bloom as the viral community composition apparently changed from the beginning to the end of the event (Moniruzzaman et al., 2016).

PCR amplification of algal virus polB and MCP gene fragments has culminated in deep-amplicon sequencing projects facilitated by 'next generation' sequencing technologies. Newly designed primers that specifically target close relatives of Prasinovirus (see below) were used in studies that uncovered immense diversity; using a very conservative cutoff of $26 \%$ nucleotide similarity to define OTUs, 17 OTUs with hundreds of different polB genotypes were observed in surface and deep chlorophyll maximum samples from three locations in the Indian Ocean (Clerissi et al., 2014). Beyond the remarkable diversity of prasinoviruses that were observed, deep-amplicon sequencing corroborated earlier results that showed that some phycodnaviruses are globally distributed; different OTUs amplified from Indian Ocean eDNA samples were most closely related to other environmental sequences from either the Southern Ocean; coastal British Columbia, Canada; coastal Hawai'i, USA; and even freshwater lakes in Ontario, Canada. A subsequent study by the same researchers expanded these results and attempted to link prasinovirus and host diversity, and determined that the unknown virus sequences that did not cluster with cultivated prasinoviruses of Bathycoccus, Ostreococcus, and Micromonas (order Mamiellales) probably infect prasinophyte species within the closely related algal order, Dolichomastigales (Clerissi et al., 2015). Clearly, ongoing isolation efforts are essential to fully appreciate the host range of uncultivated prasinoviruses, which appear to be the most diverse and abundant group of phycodnaviruses.

Most recently, a gene involved in DNA mismatch repair, MutS, has been identified as a diagnostic marker for the Megaviridae. Two new homologues of MutS (MutS7 and MutS8) were identified in the genomes of mimivirus and the algae-infecting megaviruses, and are also abundant in the Global Ocean Sampling (GOS) expedition metagenomic sequence data (Ogata et al., 2011). Following this discovery, Wilson and colleagues (2014) developed a set of PCR primers that specifically target MutS8, a MutS clade that discriminates algae-infecting megaviruses. Amplification of eDNA samples from coastal Maine, USA, revealed wide-spread occurrence of MutS8 homologues demonstrating the efficacy of this primer set for the detection of viruses most closely related to algae-infecting viruses of the Megaviridae (Wilson et al., 2014). These new primers are a welcome addition to the molecular toolkit for detecting large dsDNA algal viruses, and they will undoubtedly help resolve taxonomic questions about the megaviruses and the extent of their natural diversity.

At the other end of the viral-genome spectrum, research on the diversity of uncultivated RNA viruses in the sea began with the development of PCR primers targeting the RNA-dependent-RNApolymerase (RdRp) genes of viruses belonging 
to the order Picornavirales (Culley et al., 2003). Amplification of cDNA synthesized from environmental RNA samples from coastal British Columbia, Canada, revealed surprising diversity of picorna-like viruses of unidentified eukaryote hosts, as well as numerous sequences closely related to the RdRp sequence of HaRNAV (Culley et al., 2003). HaRNAV was the first ssRNA virus isolated that infects a microalga, the economically important, bloom forming raphidophyte Heterosigma akashiwo. Subsequent refinement of this cultivation-free approach for assessing marine RNA virus diversity extended these results by demonstrating the existence of a diverse clade of picorna-like viruses that likely infect marine protists, of which many are probably microalgae (Culley and Steward, 2007).

\section{Metagenomic studies}

Cully and colleagues (2014) also conducted a whole-genome shotgun sequencing (metagenomic) study of marine RNA virus communities. This approach was fundamentally different than the PCR-based methods mentioned above since it did not rely on amplification of targeted genes, yet the results confirmed the existence of a distinct marine picornavirus-like clade with cultivated viruses that infect microalgae (Culley et al., 2006) (Hyman and Abedon, 2018). More recent work in this area coupled RdRp-PCR and metagenomics via 'next-generation' sequencing, and suggested that marine RNA virus communities are dominated by positive-sense single-stranded RNA viruses. Once again, many of the RdRp sequences and genes from several assembled virus genomes were most closely related to cultivated algal viruses that infect several species of diatoms and the raphidophyte Heterosigma akashiwo (Culley et al., 2014).

The earliest metagenomic studies of marine RNA viruses used Sanger-based shotgun sequencing and were facilitated by the relatively small size of RNA virus genomes. Although more technically challenging, the earliest metagenomic study of DNA viruses was also based on shotgun sequencing clone libraries of viral DNA. This examination of DNA viruses in the ocean suggested that bacteriophages dominated marine virus assemblages, yet putative algal virus genes were also observed even although the filtration steps during eDNA sample prep could have excluded larger viruses of eukaryotes (Breitbart et al., 2002). Following the pioneering work of Breitbart and colleagues, other high-throughput sequencing projects targeting viruses have allowed investigators to examine virus diversity across a range of aquatic environments. All together, these efforts have led to the consistent conclusion that the extent of global viral diversity is largely unknown, and most (i.e. $>60 \%$ ) of the sequences obtained in such studies are not homologous to known sequences (Breitbart et al., 2007; Martínez Martínez et al., 2014; Mokili et al., 2012). Moreover, most of the identifiable virus sequences discovered through metagenomic studies appear to be derived from bacteriophages, but NCLDV sequences and, in particular, sequences related to phycodnaviruses and members of the 'extended mimivirus' or Megaviridae clade with algal hosts are frequently observed in metagenomes (e.g. Angly et al., 2006; Bench et al., 2007; Breitbart et al., 2004; Breitbart et al., 2002; Breitbart et al., 2007; Chow et al., 2015; Edwards and Rohwer, 2005; Kristensen et al., 2010; Mokili et al., 2012; Rosario et al., 2009; Steward and Preston, 2011; Williamson et al., 2008; Yoshida-Takashima et al., 2012). Again, this is in spite of the fact that most eDNA preparations for virus-specific metagenomic studies include filtration steps that should lead to bias against large dsDNA viruses.

Algal virus sequences have also been observed in metagenomic studies that did not specifically target viruses such as the high-profile, wholegenome shotgun sequencing of eDNA from the Sargasso Sea (Venter et al., 2004) and the Atlantic and Pacific oceans during the GOS expedition (Rusch et al., 2007). The virus sequences originally observed in these studies presumably originated from bacteriophages, and algal virus genes were not specifically noted. Furthermore analysis of the Sargasso Sea metagenome, however, revealed that unknown megaviruses with close homology to mimivirus are abundant in the Sargasso (Ghedin and Claverie, 2005). Similarly, an independent data mining project revealed that small but relevant fractions of GOS viral protein sequences were identified as eukaryote viruses ( $5 \%$ of all sequences) or mimiviruses $(0.7 \%)$ suggesting that numerous algal virus sequences were captured in the GOS eDNA samples (Williamson et al., 2008). Using DNA polymerase sequences (polB) as a reference, 'phylogenetic mapping' was also used to examine 
the distribution of large DNA viruses in the GOS sequence data (Monier et al., 2008a). Although most $(78 \%)$ of the putative viral polB sequences (811 total) were of phage origin, $14 \%$ of the sequences were mimivirus-like, and a large fraction of these (84\%) clustered with the 'extended mimiviruses' known to infect the haptophyte and chlorophyte algae Chrysochromulina ericina, Phaeocystis pouchetii, and Pyramimonas orientalis. Additionally, numerous phycodnavirus polB fragments were also observed in the GOS sequences, and most clustered with putative prasinoviruses and followed the general trend of increased abundances in temperate versus tropical waters (Monier et al., 2008a,b). Expanding upon and complementing this work, Kristensen et al. (2010) queried the Sargasso Sea and GOS metagenomes using three NCLDV core genes that have no known homologues outside this group of viruses and found that Phycodnaviridae and Mimiviridae dominated representing roughly 70 and $20 \%$, respectively, of the NCLDV sequences in these metagenomes.

In general, sequences from viruses belonging to the Phycodnaviridae tend to dominate the eukaryotic virus sequences obtained from metagenomic studies of a wide range of aquatic habitats including the marine locations noted above, an Antarctic Lake (López-Bueno et al., 2009), a temperate eutrophic lake in the continental USA (Green et al.,2015), and even perennial ponds in the central Saharan desert (Fancello et al., 2013). Analysis of 17 metagenomes collected during the Tara Oceans expedition from the Atlantic and Indian Oceans, and the Mediterranean, Red, and Arabian Seas also demonstrated the dominance of phycodnaviruses, and more specifically prasinoviruses, among NCLDVs (Hingamp et al., 2013). Based on 16 NCLDV marker genes, $52 \%$ of putative NCLDV sequences were identified as Phycodnaviridae ( $85 \%$ of the phycodnaviruses were presumed prasinoviruses), 36\% were 'Megaviridae' and the remainder were related to unclassified NCLDVs, Iridoviridae, or Asfarviridae; it is noteworthy that the polB sequence of a virus infecting the dinoflagellate Heterocapsa circularisquama is most closely related to the Asfarviridae (Ogata et al., 2009), suggesting that some of the NCLDVs detected in these metagenomes besides phycodnaviruses and megaviruses may actually infect algae. The results of this incredible survey of viruses across the world's oceans largely corroborated earlier conclusions from metagenomic studies and highlighted the fact that most of the dsDNA viruses of eukaryotes in the oceans infect algae, and frequently most of the algal viruses infect chlorophytes, or green algae, that are closely related to the family Prasinophyceae. Hence, the predominance of prasinophyte sequences in some PCR-based studies cannot be easily dismissed as due to PCR biases alone.

Many other fascinating observations of algal viruses have stemmed from metagenomic studies of viruses. For example, viral metagenomes associated with corals have revealed a remarkable diversity of sequences related to a broad range of eukaryote viruses including phycodnaviruses such as Chlorovirus and Coccolithovirus (Littman et al., 2011; Marhaver et al., 2008; Vega Thurber et al., 2008; Wegley et al., 2007). These observations permit speculation that all components of the coral holobiont, the assemblage composed of the coral animal and its symbiotic algae, protists, fungi, and bacteria, could be infected by viruses (Hyman and Abedon, 2018). Motivated by speculation that the phenomenon of coral bleaching may be caused, in part, by viral infections of symbiotic algae, Vega Thurber and coworkers coupled a study of DNA virus metagenomes of the coral Montastraea cavernosa with sequences from EST (expressed sequence tag) libraries of the coral's algal symbiont, the dinoflagellate Symbiodinium (Correa et al., 2013). This study provided compelling evidence that NCLDVs, particularly phycodnaviruses and megaviruses, and ssRNA viruses closely related to the dinoflagellateinfecting virus HcRNAV were associated with the coral algal symbiont, and therefore that viruses could be a major source of mortality for coral symbionts and play a significant role in coral health.

Metagenomics studies have also enabled assembly of nearly complete algal virus and virophage genomes from eDNA. Metagenome sequences from the 0.1-0.8 $\mu \mathrm{m}$ size fraction of Organic Lake, Antarctica, were dominated by putative phycodnavirus genes ( $>60 \%$ of reads), and three large scaffolds representing different virus genomes were identified as phycodnaviruses based on conserved polB sequences; at the time these virus genomes were classified as phycodnaviruses (Yau et al., 2011), but with current understanding of NCLDVs and the extended-Mimiviridae, it is now apparent that these genomes are more 
closely related to the algae-infecting megaviruses and are likely not part of the family Phycodnaviridae. Another surprising observation from this metagenomic project was the assembly of a complete genome of a virophage (Yau et al., 2011) that could parasitize algal viruses when infecting the same host cell (Claverie and Abergel, 2009; Fischer and Suttle, 2011; La Scola et al., 2008) (Hyman and Abedon, 2018). Virophage sequences have now been detected in metagenomic data sets collected from all over the world (Zhou et al., 2013), and seven presumably complete virophage genomes (Zhou et al., 2015) and four nearly complete algal virus genomes were assembled from the metagenomes of Yellowstone Lake, USA (Zhang et al., 2015). Three of these algal virus genomes were nested among viruses of green algae and were most closely related to prasinoviruses. The fourth algal virus genome assembly was shorter and missing several core genes, but based on its MCP sequence, it appears to be a close relative of the algal megaviruses Phaeocystis globosa virus PgV-16T and OLPV1 and 2, the Organic Lake 'phycodnaviruses' mentioned above (Zhang et al., 2015). Considering the relative dearth of isolated viruses, the ability to study nearly complete algal virus genomes assembled from environmental metagenomic sequences is remarkable and bodes well for rapid growth in knowledge of algal viruses.

Likewise, by coupling other technologies to metagenomics some researchers have opened up new avenues of investigation in algal virus research. For example, over the course of an induced algal bloom, next-generation sequencing was coupled with DNA separation methods $(\mathrm{CsCl}$ gradient and pulsed field gel electrophoresis) to specifically monitor changes in coccolithovirus (i.e. EhV) protein diversity (Pagarete et al., 2014). The results confirmed earlier PCR studies (see above), demonstrating EhV genotype diversity decreases during a bloom, but the question of how high levels of diversity can be maintained in natural EhV communities still remains. Martínez Martínez et al. (2014) combined fluorescence activated cell sorting (FACS) and metagenomics and were able to separate the virus community into distinct size classes to enrich metagenomes for specific kinds of viruses, such as giant algal viruses. This methodology minimized cellular contamination, yet many reads from the virus metagenomes were still homologous to bacterial genes, strengthening the argument that the high proportion of cellular genes in metagenomes is an artefact due to the relatively low representation of reference viral genomes in databases. Nevertheless, libraries from the largest viruses based on flow cytometry were dominated by mimiviruses and phycodnaviruses, as expected, but genotypic richness (52-163 genotypes) was surprisingly much lower than observed in previous metagenomic studies, suggesting that this method could facilitate the assembly of individual virus genomes (Martínez Martínez et al., 2014). Refinement of metagenomic flow cytometry coupled methods will undoubtedly permit exploration of algal virus diversity and ecology with unprecedented resolution.

Clearly, investigations of algal virus diversity in environmental nucleic acid samples have greatly expanded our knowledge of these globally important parasites. These studies would be much less enlightening, however, without sequence information from cultivated viruses. Indeed, the basis for identifying any gene obtained from an environmental sample is comparison to sequences from cultivated organisms. Thus, viruses that can be maintained and studied in the laboratory provide context for identifying gene sequences obtained through gene-specific PCR methods or metagenomics. Hence, the remainder of this discussion of algal virus diversity will focus on cultivated viruses - they are the basis for algal virus taxonomy and provide the most detailed glimpse into the biology of these fascinating microbial parasites.

\section{Diversity of cultivated algal viruses}

For the sake of simplicity, the following discussion of isolated viruses is organized around a hierarchical scheme based on the Baltimore classification system followed by formal taxonomy. The formal classification schemes discussed below are based on the most recent published report on the taxonomy of viruses (King et al., 2012), as well as current (as of October 2016) and historical taxonomy releases from the ICTV (http://www. ictvonline.org/virusTaxonomy.asp). As illustrated 
throughout this review of algal virus diversity, however, the pace of virus discovery in general has far surpassed the rate of formal classification. The diversity of all then-known viruses noted in the first report of the ICTV (ca. 1971) included only two families of viruses with 43 genera and 290 species. This pales in comparison to a recent report which includes seven orders, 111 families, 609 genera, and 3701 species (http://www. ictvonline.org/taxonomyReleases.asp; website accessed July 19, 2016). Given this pace of virus discovery, it is not surprising that most of the algal viruses isolated to date have not been formally classified. There are many cases, however, where the presumed classification of a virus, based on genetic relationships and host ranges, seems relatively straightforward. For these cases, the unclassified viruses will be discussed along with their formally classified close relatives.

On the other hand, the taxonomy of many algal virus isolates is not clear-cut, and notions about algal virus taxonomy have matured and changed with the discovery of new viruses. For example, before the turn of the millennium algal viruses were generally considered to be dsDNA algal viruses and were tentatively considered phycodnaviruses. Following the discovery of mimivirus (La Scola et al., 2003) and analysis of its genome (Raoult et al., 2004; Hyman and Abedon, 2018), and the more recent discovery of many other Acanthamoeba-infecting viruses, scientific perspectives on taxonomy of the larger group of dsDNA viruses (NCLDVs) that encompasses phycodnaviruses and mimiviruses have, however, rapidly changed. These discoveries (reveiwed in Abergel et al., 2015) have led to the establishment of new families in the NCLDVs such as the Marseilleviridae, and to the notion that many dsDNA algal viruses are actually members of the 'extended Mimiviridae' (Fischer, 2016), and are not as closely related to the Phycodnaviridae as originally assumed. Hence, within the following section on dsDNA viruses we have included a section describing unclassified isolates. Furthermore, because many viruses have now been isolated but not characterized with respect to their genomic composition, we have concluded our discussion of cultivated algal viruses by considering those viruses whose genome types remain unknown. This is then followed with a section on ssDNA algal viruses and then RNA algal viruses.

\section{Double-stranded DNA (dsDNA) viruses}

\section{Phycodnaviridae}

The family Phycodnaviridae is the first formal classification adopted for any group of algal viruses. The name Phycodnaviridae was proposed in 1990 and was established as a family of polyhedral dsDNA viruses that infect Chlorella-like green algae with the virus PBCV-1 as a type species within the genus Phycodnavirus. This nomenclature stood until 1998, when the ICTV accepted the proposal to rename the genus Phycodnavirus to Chlorovirus, and added the new genera Prasinovirus, Prymnesiovirus, and Phaeovirus to the Phycodnaviridae (Pringle, 1998). In addition to these four genera, the family Phycodnaviridae also includes the genera Coccolithovirus and Raphidovirus that were both added in 2004. Broadly, phycodnaviruses are defined as large (ca. 100 to $200 \mu \mathrm{m}$ diameter) icosahedral dsDNA viruses that infect algae, and that have genomes ranging from 160 to $560 \mathrm{~kb}$ (Dunigan et al., 2006; Wilson et al., 2009). Along with the recognized species of these genera, isolated viruses presumed to be members of these genera are discussed in more detail below.

\section{Chlorovirus}

As noted above, chloroviruses were the first algal viruses classified by the ICTV and they remain the only formally recognized freshwater viruses in the Phycodnaviridae. Viruses within this genus infect unicellular eukaryotic Chlorella-like algae that exist symbiotically with the protozoan Paramecium bursaria, the coelenterate Hydra viridis, or the heliozoon Acanthocystis turfacea (Bubeck and Pfitzner, 2005; Meints et al., 1981; Van Etten et al., 1982). In their symbiotic state these algae, or zoochlorellae, appear to be resistant to viral infection due to their enclosure in host vacuoles that exclude viruses (Dunigan et al., 2006). The Hydra viridis endosymbiont has not been cultured independently from its host, so its viruses have only been isolated from cells released from Hydra (Kang et al., 2005). Three strains of zoochlorellae that can be cultivated separately from their symbiont, however, have been used to isolate viruses; these particular Chlorella strains, NC64A, SAG 3.83, and Pbi, are now classified as Chlorella variabilis, Chlorella heliozoae, and Micractinium conductrix, respectively (Jeanniard et 
al., 2013). Chlorella NC64A and Chlorella Pbi are both endosymbionts of Paramecium bursaria and the viruses that infect them are generally referred to as NC64A viruses and $\mathrm{Pbi}$ viruses, respectively (Kang et al., 2005). For the sake of consistency in the names of viruses we list in Table 10.1 and Fig. 10.2 , we have used CVM in place of Pbi viruses because CVM-1 was the first Pbi virus isolated. The Acanthocystis turfacea symbiont Chlorella SAG 3.83 is host to the most recently discovered Chlorovirus species, referred to as ATCV (Bubeck and Pfitzner, 2005). The list of recognized species within the genus Chlorovirus has expanded and contracted a number of times over the years, but in the 2015 taxonomy release the ICTV recognizes 19 species of Chlorovirus including the type species Paramecium bursaria Chlorella virus 1 (PBCV-1) and 16 other NC64A viruses, as well Hydra viridis Chlorella virus 1 (HVCV-1) and Acanthocystis turfacea Chlorella virus 1 (ATCV-1). Although Chlorella Pbi viruses are distinct from NC64A viruses and are generally recognized as another species of Chlorovirus (e.g. Kang et al., 2005; Van Etten and Meints, 1999; Yamada et al., 2006), they are not yet formally classified by the ICTV.

The first observation of viruses infecting zoochlorellae stemmed from attempts to cultivate the Chlorella-like symbiont of Hydra viridis (Meints et al., 1981). A subsequent study demonstrated that similar dsDNA viruses could be isolated from Chlorella-like symbionts from other sources of Hydra and from the protozoan Paramecium as well (Van Etten et al., 1982). Interestingly, the source of these viruses, named HVCV-1 for the Hydra viridis-Chlorella virus and PBCV-1 for the Paramecium bursaria-Chlorella virus, remained unknown throughout these studies as only cells that were freshly liberated from the symbiont showed any signs of infection. Fortunately, unlike the Hydra symbiont, the Paramecium zoochlorellae (Chlorella strain NC64A) could be maintained in culture and used to screen water samples for lytic activity. Shortly thereafter, Chlorovirus host specificity was tested by inoculating NC64A and ten different free-living Chlorella species with $\mathrm{PBCV}-1$ and lysis was observed for NC64A only (Van Etten et al., 1985a). A separate study also determined that NC64A viruses could be readily isolated from freshwater bodies across the USA, demonstrating the widespread distribution of these viruses (Van
Etten et al., 1985b). The next discovery of viruses of Chlorella-like algae came from studies of German freshwaters using Chlorella $\mathrm{Pbi}$, an ex-symbiont from a European strain of Paramecium, as the host (Reisser et al., 1988). Reisser and colleagues (1991) found that the Pbi-infecting viruses (e.g. CVM) could not infect NC64A and vice versa, despite the fact that Paramecium could establish a symbiotic relationship with North American or European Chlorella strains. Hence, it was apparent that the determinants of virus specificity were not the same as the recognition factors for symbiosis (Reisser et al., 1991). Most recently, viruses of the Chlorella-like symbionts of Acanthocystis turfacea were also isolated from a German freshwater pond. This research demonstrated that these viruses, called ATCV, were closely related to, but nonetheless distinct from PBCV-1, and that the host range of the chloroviruses were limited to the hosts used for isolation; Pbi viruses only infected Chlorella $\mathrm{Pbi}$, NC64A viruses only infected Chlorella NC64A, and ATCV only infected Chlorella SAG 3.83 exsymbionts of $A$. turfacea (Bubeck and Pfitzner, 2005). A number of studies have demonstrated that all of these viruses of symbiotic Chlorella-like algae can be readily isolated from freshwaters all around the world (Dunigan et al., 2006; Kang et al., 2005; Van Etten and Meints, 1999). Unexpectedly, since it is not known if zoochlorellae can exist outside of their hosts, chloroviruses have been observed at high abundance (e.g. $>10^{5}$ plaque-forming units/ $\mathrm{ml}$ ) in natural waters despite the fact that green paramecia are relatively rare. It is possible therefore that chloroviruses have other hosts besides the strains used for their isolation (Kang et al., 2005).

While the natural history of chloroviruses is poorly understood, they are arguably the best-studied algal viruses and many details of their structure and biology have been examined. The type species of Chlorovirus, PBCV-1, is the best-studied Chlorovirus and is the source of most information about Chlorovirus biology. As summarized by Van Etten and Meints (1999), PBCV-1 attaches to the surface of the NC64A cell wall, digests the wall at the point of attachment, injects its DNA into the cell, and leaves behind an empty capsid. Indirect evidence suggests that the DNA, and possibly some viral proteins, move quickly to the nucleus where early transcription can be detected within 5 to 10 minutes post infection (p.i.). Viral DNA replication 
begins after an hour. At two hours p.i. the host cell ultrastructure is altered and capsids begin to assemble at virus assembly centres localized throughout the cytoplasm. At 5 hours p.i. completed virions, presumably filled with genomic material, can be observed throughout the cytoplasm and most particles are released from the cell by 8 hours p.i.; typical burst sizes (number of viruses produced per infected host cell) range from 200 to 350 plaqueforming units/cell, but the number of particles released is presumably much higher since only $25-50 \%$ of particles are infectious. This bacteriophage-like mechanism of infection and lytic growth is also shared by the other known Chlorella viruses (Yamada et al., 2006).

Genome sequencing of chloroviruses began with portions of the PBCV-1 genome nearly 20 years ago (Li et al., 1997), and a decade later genome sequences were obtained for at least one representative of each of the species of chlorovirus, NC64A, SAG 3.83, and Pbi, that infect each cultivated chlorella ex-symbiont (Fitzgerald et al., 2007a,b,c). These and related studies have revealed the fascinating features and coding potential of chlorovirus genomes, which contain roughly 330 to 380 protein coding sequences (Jeanniard et al., 2013). As a few examples, these algal viruses encode DNA methyltransferases and DNA site specific endonucleases (i.e. type II restriction endonuclease systems), and are the only viruses known to encode components required to glycosylate their own proteins and synthesize polysaccharides. They also encode several tRNAs. Some Chlorella virus-encoded proteins are among the smallest in their families including DNA ligases and topoisomerases, and a $\mathrm{K}^{+}$channel protein, $\mathrm{Kcv}$, that was the first virus encoded $\mathrm{K}^{+}$ channel discovered. Interestingly, some of these viruses encode a protein (vSET) that methylates cellular histones and is packaged in virions, suggesting a mechanism for viral control of host transcription. These and other remarkable features of chloroviruses have been summarized in several excellent reviews (Dunigan et al., 2006; Kang et al., 2005; Yamada et al., 2006).

Most recently, complete genome sequences for an additional 35 chloroviruses were obtained and an in-depth comparison was conducted for isolates from five continents with each subgenera, or species (i.e. NC64A, SAG 3.83, or Pbi infecting viruses), represented by at least 11 unique strains from at least two continents (Jeanniard et al., 2013). Genomes ranged from 287 to $348 \mathrm{~kb}$, with a range of sizes within each subgenera, but GC content was on average highest for the SAG viruses (49\%) and lowest for NC64A (40\%) with the Pbi viruses between. Furthermore, genome collinearity as well as a phylogeny based on concatenated sequences of 32 core protein families demonstrated that chlorovirus genomes clustered cleanly into the three known species: Pbi viruses, NC64A viruses (PBCV-1 and relatives), and SAG viruses (ATCV-1 and relatives), but the relationship among chlorovirus species was not echoed among the hosts, demonstrating that host-virus coevolution did not drive chlorovirus divergence. A single Pbi virus isolate, NE-JV-1, was distinct from the other three species with only $73.7 \%$ amino acid identity to the other Pbi viruses compared with averages of $92.6 \%, 95.0 \%$, and 97.4\% identity for the other NC64A, SAG and Pbi viruses, respectively. Hence, NE-JV-1 may represent a previously unknown subgroup of chloroviruses, one that serves to highlight our limited knowledge of the full extent of their diversity. With respect to the CDSs (coding sequences) themselves, their lack of homology to host genes suggests that gene capture, or horizontal gene transfer (HGT) of host genes was a rare event in the evolutionary history of chloroviruses. Fascinatingly, more than half of the gene families in chloroviruses originated after the chlorovirus species diverged and many of these have no known homologues in public databases, or even among the other chlorovirus species, leaving questions about the genomic origins of chlorovirus CDSs unanswered (Jeanniard et al., 2013).

Research on the chloroviruses, undoubtedly the best studied algal viruses, has revealed the incredible complexity and coding capacity of the phycodnaviruses. Despite a wealth of information about the biochemistry, metabolic capabilities, genomics, and life histories of chloroviruses, it appears that many novel chloroviruses await discovery, and we cannot yet fully comprehend their evolutionary history. An even more fundamental aspect of chloroviruses, the identity of their hosts in natural waters, is not yet well established; it seems likely that there are other hosts for these viruses that have been isolated using permissive ex-symbiotic zoochlorellae hosts. Hence a deeper understanding of their role in aquatic ecosystems likely awaits researchers studying this fascinating group of algal viruses. 


\section{Coccolithovirus}

The genus Coccolithovirus consists of a group of viruses that infect Emiliania huxleyi, a unicellular haptophyte alga (algal division Haptophyta, also referred to as Prymnesiophyta). Haptophyte algae such as E. huxleyi produce calcium carbonate coccoliths and can form vast coastal and mid-oceanic blooms (Holligan et al., 1993). E. huxleyi has a global distribution from the tropic to subarctic waters, and plays a key role in $\mathrm{CO}_{2}$ cycling and dimethyl sulphide production, thus making it a globally important species in marine primary productivity, sediment formation, and climate (e.g. Charlson et al., 1987; Franklin et al., 2010; Westbroek et al., 1993). The first indication that viruses could play a role in the bloom dynamics and ecology of $E$. huxleyi came from observations of abundant viruslike particles following the demise of blooms in mesocosms manipulated with nutrients (Bratbak et al., 1993).

Coccolithoviruses were isolated independently by different research teams and were found in numerous samples from the English Channel and Norwegian coastal waters (Castberg et al., 2002; Schroeder et al., 2002; Wilson et al., 2002). Wilson et al. (2002) initially reported the isolation of two strains of a virus (EhV-84 and EhV-86) that could infect Emiliania huxleyi strain CCMP1516. A subsequent study of 10 different EhV strains found that they had similar host ranges, infecting at least three strains of E. huxleyi (CCMP374, CCMP1516, and strain L), but some E. huxleyi strains (CCMP 370, 373, and 379) were not susceptible to infection (Schroeder et al., 2002). Similarly, Castberg et al. (2002) tested the lytic activity of three EhV isolates (EhV-99B1, EhV$2 \mathrm{~KB} 1$, and $\mathrm{EhV}-2 \mathrm{~KB} 2$ ) and found that they all infected the three strains of E. huxleyi tested, but other algae including Phaeocystis pouchetii, Pyramimonas orientalis, Chrysochromulina ericina, and Micromonas pusilla were not susceptible. Phylogenetic analysis of E. huxleyi virus polB genes demonstrated a close affiliation with other phycodnaviruses (Castberg et al., 2002; Schroeder et al., 2002). It was suggested, however, that the $E$. huxleyi viruses represent a novel Phycodnaviridae genus that was not closely related to Prymnesiovirus, a genus of viruses which also infect haptophyte algae (described below). Nevertheless, phylogenetic analysis of several NCLDV core genes of
EhV-86 corroborated its placement in the Phycodnaviridae (Allen et al., 2006b).

E. huxleyi viruses were classified by the ICTV in 2004 as a new Phycodnaviridae genus, Coccolithovirus with Emiliania huxleyi virus 86 (EhV-86) designated as the type species. Although 12 other tentative species were listed in the proposal, EhV-86 is the only recognized Coccolithovirus. The EhV-86 virion is between 170 and $175 \mathrm{~nm}$ in diameter, and encapsidates a circular dsDNA genome of 407,339 bp (Wilson et al., 2005). Within this large genome are 25 of the 40 to 50 conserved genes within the NCLDVs, but EhV-86 also encodes six RNA polymerase subunits, all of which are expressed, a unique feature within the Phycodnaviridae. This, in combination with a novel promoter, could indicate that EhV-86 encodes its own transcription machinery, allowing transcription to occur within the host cytoplasm. Additionally, at least four genes within EhV-86 have been linked to sphingolipid biosynthesis (Wilson et al., 2005). Sphingolipid biosynthesis produces ceramide, a compound that suppresses cell growth and signals apoptosis. This, in combination with the fact that EhV-68 also encodes eight proteases, which are also linked to ceramide-induced apoptosis, suggests that the virus induces host cell apoptosis for progeny dissemination (Frada et al., 2008; Wilson et al., 2005).

Nearly complete genome sequences have been determined for several other virus strains including EhV-18, EhV-84, EhV-88, EhV-145, EhV-156, EhV-163, EhV-164, EhV-201, EhV-202, EhV-203, EhV-207, and EhV-208. This work has revealed not only high levels of homology, but also considerable CDS diversity among these isolates and a fascinating complement of genes such as those encoding tRNAs, methyltransferases, glycosylases, and a sphingolipid biosynthesis pathway, for example (Allen et al., 2006a; Nissimov et al., 2011a,b, 2012a,b; Pagarete et al., 2013). Over the last decade Coccolithovirus has emerged as one of the most thoroughly studied algal virus model systems; coupled with available genomic information, studies of these viruses in the wild and in manipulated mesocosm experiments will undoubtedly help drive advances in algal virus research.

\section{Phaeovirus}

As of the 2015 release of viral taxonomy from ICTV, genus Phaeovirus contains nine species that 
all infect reproductive cells of certain macrophytic brown algae (class Phaeophyceae): Ectocarpus fasciculatus virus a (EfasV-a), Ectocarpus siliculosus virus 1 (EsV-1), Ectocarpus siliculosus virus a (EsV-a), Feldmannia irregularis virus a (FirrV-a), Feldmannia species virus (FsV), Feldmannia species virus a (FsVa), Hincksia hinckiae virus a (HincV-a), Myriotrichia clavaeformis virus a (MclaV-a), and Pilayella littoralis virus 1 (PlitV-1). EsV-1 has been designated as the type species, and at least one other virus closely related to members of the genus Phaeovirus has been isolated, but is not classified by the ICTV.

The unclassified, putative Phaeovirus, Feldmannia simplex virus 1 (FlexV-1), infects the filamentous brown algae $F$. simplex. It has an icosahedral capsid with a diameter of ca. 120 to $150 \mathrm{~nm}$ and a $220 \mathrm{~kb}$ dsDNA genome (Friessklebl et al., 1994). Similarly, all phaeoviruses have icosahedral capsids ranging from 120 to $180 \mathrm{~nm}$ in diameter and dsDNA genomes that range in size from ca. 150 to $340 \mathrm{~kb}$ (Kapp et al., 1997; Maier et al., 1998). Unique among members of family Phycodnaviridae, phaeoviruses infect macroalgae, specifically brown filamentous algae belonging to the order Ectocarpales. Generally, the unicellular gametes or swimming spores of these filamentous brown algae lack cell walls and are susceptible to viral infection while the mature, multicellular brown algae are resistant to new infections. While initial infection occurs in the unicellular gamete or spore, virus multiplication occurs in the gametangia or sporangia tissues of mature algae (Kapp et al., 1997). Additionally, the only reports of latent infections in the family Phycodnaviridae are of phaeoviruses, where evidence for a latent lifestyle stems from observations of Mendelian segregation of viral genomes following meiosis (Müller, 1991). Like most algal viruses, host specificity in phaeoviruses is generally rigid, with most studies reporting viruses infecting only a single host species. EsV-1, however, can infect and successfully replicate in the brown algae Kuckuckia kylinii (Müller, 1992) as well as in its main host, E. siliculosus. EsV-1 can also infect F. simplex (based on observation of abnormal morphological symptoms), although TEM observations did not reveal any intact, recognizable virions (Müller and Parodi, 1993). EfasV can similarly infect E. siliculosus (based on both observed pathologic symptoms and PCR detection of a viral gene fragment), although the virions produced were apparently not released and, moreover, were not infectious; attempted infection experiments using the infected thalli as virus donors were unsuccessful (Müller et al., 1996).

The complete genome sequences of EsV-1 (Delaroque et al., 2001) and FsV-158 (Schroeder et al., 2009) and a partial genome of FirrV-1 (Delaroque et al., 2003) have been determined. Interestingly the viruses infecting Feldmannia sp. (FsV) exist in two forms that have genomes of either 158 or $178 \mathrm{~kb}$. The genome size of the smaller FsV, FsV-158 (the entire genome is actually $154,641 \mathrm{bp}$ ), makes it one of the smallest genomes in all of Phycodnaviridae, and, moreover, it shares only ten core genes with other NCLDVs, far less than the typical NCLDV complement of 31 core genes. FsV-158 has the fewest CDSs of any phycodnavirus (150), but almost $90 \%$ of these have orthologues in FirrV-1 and EsV-1. On the other hand, as is the case for most large dsDNA algal viruses, only a small proportion of these CDSs (25\%) have significant homologies to genes in sequence databases that have known cellular functions including DNA replication, recombination, repair, and modification; integration and transposition; transcription; nucleotide metabolism; protein and lipid synthesis, modification, and degradation; and signalling (for example, Schroeder et al., 2009).

Phylogenetic relationships of the core genes shared among these sequenced phaeoviruses have confirmed the recent evolutionary history of the phaeoviruses relative to other NCLDVs. Furthermore, the phylogenetic relationships between phaeoviruses and other phycodnavirus genera reflect the evolutionary relationships of their host algae (Schroeder et al., 2009), suggesting an evolutionary history of phycodnaviruses that is at least as old as the lineages of algae they infect; the separation of Chlorophyte and Phaeophyte algae is estimated at ca. 1.5 billion years ago (Yoon et al., 2004), so it is reasonable to assume that the common ancestor of some phycodnaviruses, in particular Chlorovirus and Phaeovirus, is at least this old. Like other types of algal viruses, the full extent of Phaeovirus diversity and the breadth of hosts they infect cannot yet be fully appreciated. Nevertheless, it is easy to imagine that this ancient group of viruses has had an important role in the speciation and microevolution of at least some types of brown algae. 


\section{Prasinovirus}

According to the ICTV, the genus Prasinovirus currently includes two species: the type species Micromonas pusilla virus SP1 (MpV-SP1) and Ostreococcus tauri virus OtV5. In 1998, Prasinovirus was named as the second genus in the Phycodnaviridae with MpV-SPI as the sole species (Pringle, 1998), and OtV5 was added as a second species in 2011. Although there are only two species formally classified as Prasinovirus, it is clear that there are many other viruses infecting prasinophyte algae that are similar in morphology and genome size to MpV-SP1 and OtV5, and they share closely related homologues of the NCLDV core gene, polB. All of these putative prasinoviruses infect algae within the order Mamiellales including the genera Micromonas, Ostreococcus, and Bathycoccus, so it seems apparent that these closely related viruses should all be classified as prasinoviruses and, hence, they will be discussed in the following paragraphs. To clarify the term Prasinophyceae, this formerly recognized class of chlorophyte algae (i.e. green algae) has been shown to be polyphyletic and classification schemes within the green algae are the subject of ongoing debate (Brodie and Lewis, 2007). According to the Taxonomy Browser on the National Center for Biotechnology Information (NCBI), U.S. National Library of Medicine website (www.ncbi.nlm.nih.gov/taxonomy/; accessed 20 July 2016), the phylum Chlorophyta includes the unranked group 'prasinophytes' within which the class Mamiellophyceae and the order Mamiellales reside. All of the hosts of the prasinoviruses are species within the order Mamiellales.

As noted in the introduction, the first reports of the isolation of a eukaryotic algal virus described viruses that infect the marine prasinophyte alga Micromonas pusilla (Mayer and Taylor, 1979; Waters and Chan, 1982). A decade later, Cottrell and Suttle (1991) isolated seven genetically distinct strains of $M$. pusilla viruses from coastal waters of British Columbia, California, New York, and Texas, as well as the central Gulf of Mexico. A few years later, viruses that were morphologically similar to MpV-SP1 were isolated from the North Atlantic, and were highly specific for M. pusilla; 11 other diverse microalgal species were challenged with these viruses, but no infection was observed (Sahlsten, 1998). Similar viruses were also isolated from the Gulf of Naples in the Mediterranean Sea
(Zingone et al., 1999) suggesting that MpVs, like their hosts (Slapeta et al., 2006), are ubiquitous in the world's oceans. For this study of MpVs in the Mediterranean, five different strains of the host $M$. pusilla were used to titre $\mathrm{MpVs}$ revealing intraspecific variability in the host's susceptibility to $\mathrm{MpV}$ (Zingone et al., 1999). Eventually, two novel $M$. pusilla viruses, MpVN1 and MpVN2, were isolated by Zingone et al. (2006) from the Gulf of Naples. Surprisingly, these viruses were morphologically and genetically distinct, one featuring a tail-like structure, and they had different patterns of infectivity against the 11 strains of $M$. pusilla isolates that were screened. Based on amplification with the conserved algal virus polB PCR primers, MpVN2 seems related to known prasinoviruses, but the primers were unsuccessful on MpVN1, suggesting that it might not be closely related (Zingone et al., 2006). Clearly, MpVs are widely distributed in nature, and the extent of their diversity is not yet known.

Following the isolation of these M. pusilla viruses, the next Prasinovirus isolate reported in the literature was OtV5, the second formally recognized species of Prasinovirus that infects the Mamiellophyceae Ostreococcus tauri. Like the MpVs, OtV5 appeared to be highly host specific; the virus did not lyse any other algal species tested including other strains of Ostreococcus tauri (Derelle et al., 2008). A more recent study by Clerissi et al. (2012) demonstrated that most but not all isolates of $\mathrm{OtV}$ are species or strain specific. Although most (34) of the 40 virus strains examined were O. tauri-specific, the others were able to lyse other species of Ostreococcus such as O. lucimarinus or $O$. mediterraneus and one viral isolate was able to lyse all three Ostreococcus species. None of the viruses, however, could infect the strains of the other Mamiellophyceae, Micromonas and Bathycoccus, that were tested (Clerissi et al., 2012). Nevertheless, novel prasinoviruses have been isolated from a strain of Micromonas pusilla (strain RCC1109) other than the one originally used to isolate $\mathrm{MpVs}$ (strain UTEX 991, or CCMP 491).

In general, prasinoviruses appear to be widespread in nature. For example, hundreds of Ostreococcus viruses that can be distinguished based on sequence information or host specificity have been obtained from marine locations around the world including the South and North Pacific Ocean, 
North Atlantic Ocean, Mediterranean Sea, coastal Argentina, and the English Channel (Bellec et al., 2010; Derelle et al., 2008; Manrique et al., 2012; Weynberg et al., 2009). That said, it is likely that some prasinoviruses are cosmopolitan while others are geographically constrained. A recent study of the global distribution of Ostreococcus viruses provided the observation that $O$. tauri viruses were restricted to coastal lagoons whereas $O$. lucimarinus viruses were detected in distant ocean samples from across the planet. Interestingly, there was no evidence for biogeography among $O$. lucimarinus viruses, i.e. no relationship was found between the phylogenetic and geographic distances of individual virus strains (Bellec et al., 2010).

Besides Micromonas and Ostreococcus, another prasinophyte genus is a host to viruses presumed to be prasinoviruses. Samples collected from the Mediterranean Sea over a 2-year period harboured diverse viruses that could infect several mamiellophycean algae including Micromonas, Ostreococcus, and Bathycoccus (strain RCC1105) (Bellec et al., 2009). Based on their partial polB sequences, all of these viruses were clustered among the formally recognized prasinoviruses $\mathrm{MpV}-\mathrm{SP} 1$ and OtV5, suggesting that they are all bona fide prasinoviruses. The novel Micromonas viruses that grouped as their own distinct clade separate from $\mathrm{MpV}$ were named $\mathrm{MiV}$ as they were genetically distinct from other MpVs. Likewise, the Bathycoccus viruses, named $\mathrm{BpV}$, also formed a distinct clade suggesting that they should be recognized as a new species of Prasinovirus. Recent discoveries of diverse, novel prasinoviruses such as the ones noted here highlight a recurring theme in algal virus research, that the extent of algal virus diversity in general, and prasinoviruses specifically, is largely unknown.

\section{Prymnesiovirus}

Describing the diversity of Prymnesiovirus is challenging because many different viruses infecting prymnesiophyte algae (also interchangeably referred to as haptophytes) have been isolated, but so far only one, CbV-PW1, has been formally classified. Because of their dsDNA genomes and similar morphology, most viruses of prymnesiophytes were originally assumed to be phycodnaviruses, but it is now apparent that while they are all NCLDVs, they do not all share a recent common ancestor and only some should be classified within the
Phycodnaviridae. It is also noteworthy that the Coccolithovirus EhV (described above) also infects a haptophyte algal species and is classified as a phycodnavirus, but it is more closely related to other phycodnaviruses which do not infect haptophytes. Although it seems certain that many prymnesiophyte viruses are not species of Prymnesiovirus and await formal classification, it would be an oversight to not mention their discovery within this section. Hence, to recognize the history of and progress in this area of algal virus research, the unclassified algal viruses of prymnesiophytes will be briefly described here, and their taxonomic status will also be noted below in the section 'Unclassified dsDNA algal viruses'.

The type species of Prymnesiovirus, CbV-PW1, is an icosahedral virion ca. $170 \mathrm{~nm}$ in diameter that infects the marine haptophyte Chrysochromulina brevifilum, a member of the algal class Prymnesiophyceae. Two strains of CbV (PW1 and PW3) were isolated from numerous seawater samples collected from coastal Texas, USA. Interestingly, lytic viruses for $C$. brevifilum were detected at all sampling locations, but were only present at certain times of the year (Suttle and Chan, 1995), thus providing some of the earliest evidence for seasonality of algal viruses. The next haptophyte virus discovered was PpV01, a virus with phycodnavirus morphology from Norwegian fjords that infected two strains of Phaeocystis pouchettii but did not infect strains of $P$. globosa or P. antarctica (Jacobsen et al., 1996). Soon after, two viral isolates were described that infected the haptophyte Chrysochromulina ericina (CeV-01B and PoV-01B). Surprisingly, one of these infected the prasinophyte algae Pyramimonas orientalis as well and was thus named PoV (Sandaa et al., 2001). $\mathrm{PoV}$ and $\mathrm{CeV}$ were tested against a range of other algae and were not infectious, but PoV was one of the first algal viruses reported to infect more than a single species of algae. Both of these viruses were morphologically similar to phycodnaviruses and were thought to belong with the Phycodnaviridae, but it was notable that they had much larger genomes $(>500 \mathrm{~kb})$ compared to typical phycodnaviruses (Sandaa et al., 2001).

Following the discovery of $\mathrm{CeV}$ and PoV, 24 strains of viruses infecting the haptophyte Phaeocystis globosa were isolated from Dutch coastal waters and a subset were genetically characterized (Brussaard et al., 2004). Based on polB sequences, seven 
P. globosa viruses $(\mathrm{PgV})$ clustered most closely with CbV-PW1 suggesting they belonged in the Phycodnaviridae. Also, it was noted in that study that conserved phycodnavirus PCR primers for polB, an important phycodnavirus marker gene (see 'PCR studies' above), did not amplify genes for some types of prymnesiophyte-infecting viruses such as $\mathrm{PpV}$ (Brussaard et al., 2004), suggesting that they were taxonomically distinct from prymnesiophyteinfecting phycodnaviruses. Further studies on twelve other Dutch isolates of $\mathrm{PgV}$ demonstrated that there were actually two groups of morphologically distinct viruses that infected twelve P. globosa strains with variable host ranges, but they did not infect any of the other 27 algae tested. The so-called Group I PgVs had larger genomes and capsid diameters (466 kb and $150 \mathrm{~nm}$, respectively), whereas Group II PgVs had $177 \mathrm{~kb}$ genomes packaged in $100 \mathrm{~nm}$ virions (Baudoux and Brussaard, 2005). To further complicate the natural history of Phaeocystis globosa viruses, another virus was isolated from the UK (PgV-102P) that, based on polB sequences, did not cluster with the PgVs characterized by Brussaard et al. (2004), but was instead most closely related to CbV-PW1 (Wilson et al., 2006).

Most recently, three new haptophyte viruses, $\mathrm{HeV}$ RF02, PkV RF01, and PkV RF02, that infect Haptolina ericina and Prymnesium kappa (formerly called Chrysochromulina ericina and C. kappa, respectively) were isolated from Norwegian waters (Johannessen et al., 2015). Two of these viruses, HeV RF02 and PkV RF01, could infect both of these haptophyte species, but they did not infect other haptophytes. Nonetheless, these viruses represent one of the few cases of an algal virus that can infect multiple species of hosts, in this case belonging to two different genera (Johannessen et al., 2015). Around the same time, the first freshwater haptophyte virus was isolated from Lake Ontario, Canada (Mirza et al., 2015). This virus, CpV-BQ1, that infects the freshwater alga Chrysochromulina parva, has typical phycodnavirus morphology and its polB sequence clusters with CbV-PW1 suggesting that it should be classified in the Phycodnaviridae. On the other hand, the fact that CpV's major capsid protein sequences and large genome size (approximately $485 \mathrm{~kb}$ ) are more similar to the Group 1 PgVs and the other haptophyte viruses $(\mathrm{CeV}, \mathrm{PpV}, \mathrm{HeV}$, and $\mathrm{PkV}$ ) and are not most closely related to CbV-PW1 blurs its taxonomic affiliation (Mirza et al., 2015).
Traditionally, viruses like $\mathrm{CeV}$ and $\mathrm{PoV}$ that had large dsDNA genomes and infected haptophyte algae were tentatively classified as phycodnaviruses (Sandaa et al., 2001). Others, such as PpV were not classified at the time of their discovery (Jacobsen et al., 1996), mainly because the genus Prymnesiovirus had not been established by the ICTV until 1998. As noted below in the section 'Unclassified dsDNA algal viruses', the discovery of other types of NCLDVs and the advent of viral genomics has helped refine the taxonomic relationships of many dsDNA algal viruses.

For example, with respect to its polB sequence, $\mathrm{PpV}$ is undoubtedly an NCLDV but it does not cluster within the Phycodnaviridae. Rather, it clusters among other types of large dsDNA viruses (Larsen et al., 2008; Monier et al., 2008b) and should be considered a member of the so-called 'extended Mimiviridae' (Fischer, 2016). Likewise, ongoing research has demonstrated that all of the haptophyte viruses mentioned in this section are related and can all be considered NCLDVs, or 'megaviruses', but only some are closely related to the Prymnesiovirus type species CbV-PW1 and can be considered members of the Phycodnaviridae. Although some PgVs, namely Group II isolates, are closely related to CbV (Brussaard et al., 2004; Santini et al., 2013), the genome sequence of the $\mathrm{PgV}$ Group I isolate 16T demonstrated that this isolate shared features found only in mimivirus genomes. Moreover, based on its polB sequence, PgV-16T clustered with the other prymnesiophyte-infecting viruses that are most closely related to mimiviruses, namely $\mathrm{CeV}$ and $\mathrm{PoV}$ (Santini et al., 2013).

To summarize, the genus Prymnesiovirus includes only one recognized species, CbV-PW1, but based on polB phylogenies several other prymnesiophyteinfecting viruses such as PgV Group II, and possibly CpV-BQ1 appear to be closely related and could be classified within this genus. On the other hand, several prymnesiophyte-infecting viruses with large genomes, greater than $400 \mathrm{~kb}$ such as $\mathrm{CeV}, \mathrm{HeV}$, $\mathrm{PgV}$ Group I, PkV, PoV, and PpV, are more closely related to Mimivirus and should not be considered as members of the Phycodnaviridae.

\section{Raphidovirus}

The genus Raphidovirus currently consists of only one species, $\mathrm{HaV}$ (Heterosigma akashiwo virus 01 ), which infects Heterosigma akashiwo, a widespread 
microalga that is found in coastal waters of the temperate and subarctic Atlantic and Pacific Oceans. Importantly, $H$. akashiwo has been associated with recurring red tides in Japan, aquaculture losses in British Columbia, Washington, Chile, and New Zealand (Hallegraeff and Hara, 2004; Tomaru et al., 2008), and its lytic viruses have been implicated in bloom termination (Nagasaki et al., 1994a; Nagasaki et al., 1994b). A virus infecting H. akashiwo was initially isolated using a single host strain, but its host range was tested by screening lysates against four other strains of $H$. akashiwo and a range of other species belonging to several different classes of algae. Only two strains of $H$. akashiwo were sensitive to the virus that was described as a $202 \mathrm{~nm}$ diameter naked icosahedral virion with a dsDNA genome (Nagasaki and Yamaguchi, 1997). Shortly after, several different strains of morphologically similar viruses of Heterosigma were isolated and the strain $\mathrm{HaV01}$ was characterized in greater detail revealing that the virus has a latent period of 30 to 33 hours with mature particles appearing within the host cytoplasm 24 hours post infection, and approximately 770 infectious particles released per lysed cell (Nagasaki et al., 1999). Based on pulsed field gel electrophoresis, the dsDNA genome of HaV01 was approximately $294 \mathrm{~kb}$, and sequence analysis of the virus's polB gene revealed its close taxonomic affiliation with other dsDNA algal viruses within the Phycodnaviridae (Nagasaki et al., 2005). The genome is now partially sequenced and annotated, and many of its genes are highly similar to other phycodnavirus or, interestingly, mimivirus genes (Tomaru et al., 2008). Although Heterosigma akashiwo virus 01 is recognized by the ICTV as a member of the Phycodnaviridae, it is worth noting that another dsDNA virus of $H$. akashiwo has been isolated from British Columbia, Canada, coastal waters. The Canadian isolate, named OIs1, has only been partially characterized and may not exist in pure culture, but since it has a smaller genome and particle size than $\mathrm{HaV}$ (Lawrence et al., 2006), it is not likely that OIs1 is related to Raphidovirus.

Ecological studies of $\mathrm{HaV}$ demonstrated that Japanese waters contained numerous strains of both $H$. akashiwo and its co-occurring lytic viruses, and complex spectra of host-strain susceptibility and virus-strain infectivity has been observed during several studies. Thus, $\mathrm{HaV}$ infectivity is beyond species specific, but is actually strain specific and moreover, depending on the host-virus pair, not all infections lead to complete lysis of the host culture (Nagasaki and Yamaguchi, 1998). Together, complicated patterns of lytic activity with some host strains displaying some degree of resistance to infection as well as complex virus-host succession patterns observed during the course of $H$. akashiwo blooms demonstrate that this lytic virus plays an intimate but incredibly complex role in the ecology of its harmful bloom-forming algal host (Tarutani et al., 2000; Tomaru et al., 2008; Tomaru et al., 2004). The fact that there are multiple types of viruses infecting $H$. akashiwo, such as Marnavirus (an ssRNA virus described below), means that this virus-host consortia is even more complex and fascinating and could serve as an excellent model system to address questions related to competition among viruses.

\section{Dinodnavirus, a dsDNA algal virus not assigned to a family}

The proposed genus Dinodnavirus has one species, Heterocapsa circularisquama DNA virus 01 (HcDNAV01). HcDNAV01 is one of two viruses isolated that infect the dinoflagellate $H$. circularisquama, and is thus far the only dsDNA virus isolated that infects any dinoflagellate species (Nagasaki, 2008). Genomic data (Correa et al., 2016; Correa et al., 2013) and evidence from electron microscopy, however, suggest that other dsDNA viruses related to NCDLVs are associated with endosymbiotic dinoflagellates (Symbiodinium) of scleractinian corals (Correa et al., 2016; Lawrence et al., 2014; Wilson et al., 2001). Originally classified within Phycodnaviridae, HcDNAV01 has several characteristics in common with other NCDLVs such as cytoplasmic replication in a viroplasm (an organized virus replication inclusion body seen in infected cells) and large (180 to $210 \mathrm{~nm}$ dia.) icosahedral virions (Tarutani et al., 2001) encapsidating a large (approximately $364 \mathrm{~kb}$ ) dsDNA genome (Nagasaki et al., 2005). Analysis of HcDNAV01's polB sequence suggests that it is most closely related to African swine fever virus (ASFV), the only member of the Asfarviridae, a distinct family of NCLDVs closely related to Phycodnaviridae (Ogata et al., 2009). It was upon this realization that Dinodnavirus was proposed as a genus, but whether it is close enough to ASFV to warrant its classification as a genus in Asfarviridae is 
not yet known and will require further characterization.

So far, HcDNAV01 is known to infect only $H$. circularisquama; no lysis was observed when $\mathrm{HcDNAV}$ was used to challenge other types of algae including nine other species of Dinophyceae, four of Bacillariophyceae, two of Prymnesiophyceae, four of Raphidophyceae, and one each of Chlorophyceae, Cryptophyceae, Euglenophyceae, and Eustigmatophyceae (Tarutani et al., 2001). HcDNAV01 however can infect multiple strains of $H$. circularisquama and successfully infects its hosts at a wide range of temperatures $\left(15-30^{\circ} \mathrm{C}\right)$, has a latent period (time from initial infection until production of infectious virions) of $40-56 \mathrm{~h}$, and a burst size of $1.8 \times 10^{3}$ to $2.4 \times 10^{3}$ infectious particles/cell (Nagasaki et al., 2003). The ecological importance of HcDNAV01 has not been fully explored, but it has a widespread distribution along the western coast of Japan (Tomaru and Nagasaki, 2004) and often co-occurs with HcRNAV, suggesting an interesting ecological relationship between these two very different types of $H$. circularisquamainfecting viruses (Tomaru et al., 2009).

\section{Unclassified dsDNA algal viruses}

As noted previously, many dsDNA viruses remain unclassified (Fig. 10.2). Whereas the taxonomic affiliation seems clear for some unclassified algal viruses, the evolutionary history and therefore the classification scheme is less clear or completely unknown for many others. For example, the dsDNA viruses Ols1 that infects the raphidophyte Heterosigma akashiwo (Lawrence et al., 2006; Lawrence et al., 2002) and MpVN1 that infects the prasinophyte Micromonas pusilla (Zingone et al., 2006) were not characterized in detail beyond reporting their genome as dsDNA, so it is not yet known if these viruses are phycodnaviruses, or even members of the NCLDVs, or Megavirales (Colson et al., 2013). For other viruses such as the Tetraselmis striata virus (TsV-N1), more detailed characterization has not provided a clear taxonomic affiliation. $\mathrm{TsV}$ is a small $(60 \mathrm{~nm}$ dia.) virus with a $31 \mathrm{~kb}$ genome that is distinct from other dsDNA algae viruses allowing the conclusion that it is not a member of the Phycodnaviridae, but because this virus is genetically unique it cannot be placed within extant virus genera or families (Pagarete et al., 2015).
As well, the viruses $\mathrm{CeV}, \mathrm{HeV}, \mathrm{PgV}$ Group I, $\mathrm{PkV}, \mathrm{PoV}$, and $\mathrm{PpV}$ that infect prymnesiophyte, or haptophyte algae should not be considered prymnesioviruses (see 'Pyrmnesiovirus' above) because they are more closely related to mimiviruses than the Prymnesiovirus type species $\mathrm{CbV}$ (Hyman and Abedon, 2018). Genomic characterization of the Aureococcus anophagefferens virus $\mathrm{AaV}$ provided clear evidence that it was member of the 'Megaviridae' or 'extended Mimiviridae' (Moniruzzaman et al., 2014) and is another example of a giant dsDNA algal virus within the NCLDVs but outside of the Phycodnaviridae. Similarly, the dinoflagellate-infecting virus $\mathrm{HcV}$ (Dinodnavirus, described above) has characteristics of NCLDVs, but does not appear to be a close relative of either the Mimiviridae or Phycodnaviridae. Instead, based on its polB sequence, $\mathrm{HcV}$ appears most closely related to Asfarviridae. It is notable that a recent analysis of DNA mismatch repair genes $(M u t S)$ in several dsDNA algal viruses including $\mathrm{CeV}, \mathrm{HcDNAV}, \mathrm{PoV}$, and $\mathrm{PpV}$ (Ogata et al., 2011) provided additional evidence supporting the hypothesis that these algal viruses are more closely related to mimiviruses than to phycodnaviruses. On the other hand, based on several diagnostic characteristics, the most recently discovered dsDNA dinoflagellate virus which infects Heterocapsa pygmaea, HpygDNAV, was considered a putative phycodnavirus (Kim et al., 2012). Because its genome awaits detailed characterization, however, this suggested classification is tentative.

The taxonomic affiliation of some unclassified dsDNA algal viruses seems clear and places them within the Phycodnaviridae, yet they await formal classification by the ICTV. For the most part, host taxonomy, viral morphology, and sequences of the NCLDV core gene polB have provided evidence that these viruses are close relatives of species within established genera and have permitted their tentative classification. Most of these viruses were already discussed above in the sections describing their closest relatives within established genera. For example, as noted above in the section describing Prasinovirus, the prasinophyte-infecting viruses $\mathrm{BpV}, \mathrm{MiV}$, and MpVN2 that infect Bathycoccus and Micromonas, respectively, are most closely related to the Prasinovirus type species MpV-SP1 and should be classified as such. Likewise, the virus FlexV of the macrophytic brown algae Feldmannia is a putative 
Phaeovirus, strains of Phaeocystis globosa virus in group II and possibly the freshwater haptophyte virus $\mathrm{CpV}$ are putative Prymnesiovirus species, and the Chlorella Pbi-infecting virus CVM-1 and its close relatives are most certainly species of Chlorovirus. Algal virus discovery over the last couple of decades has far outpaced the rate of virus classification, so algal virus researchers have assigned tentative classifications based on the known characteristics of the viruses they study. In many cases these informal classification schemes are well justified and it seems likely that they will eventually be adopted by the ICTV.

It is the hallmark of scientific progress that we can now look back at the early years of algal virus discovery and realize how naïve we were and how far the study of these fascinating parasites has come. It is now apparent that there are many more types of viruses that infect algae besides the dsDNA viruses of the Phycodnaviridae and, moreover, not even all dsDNA algal viruses are phycodnaviruses. Only through ongoing isolation and characterization efforts will the taxonomy of dsDNA algal viruses be well resolved. It is becoming more apparent with every new isolate that the 'tree' of algal viruses is actually a 'shrub' with many new viruses filling in the gaps between known taxa creating an almost continuous spectrum of algal viruses with shared characteristics.

\section{Single-stranded DNA (ssDNA) viruses}

\section{Bacilladnavirus and similar viruses}

Currently, all isolated algal viruses with ssDNA genomes infect various species of diatoms. The only formally classified ssDNA algal virus is the Chaetoceros salsugineum nuclear inclusion virus (CsalDNAV), isolated by Nagasaki et al. (2005c), and it is therefore the type species of the genus Bacilladnavirus. At least eight other genetically similar diatom viruses have been isolated, however, and proposed as additional species of Bacilladnavirus, including: CdebDNAV (Tomaru et al., 2008b), ClorDNAV (Tomaru et al., 2011b), CtenDNAV (Tomaru et al., 2011a), TnitDNAV (Tomaru et al., 2012), Csp05DNAV (Toyoda et al., 2012), Csp07DNAV (Kimura and Tomaru, 2013), CsetDNAV (Tomaru et al., 2013b), and CtenDNAV type II (Kimura and Tomarua, 2015). All of these viruses were isolated from Japanese coastal waters and, except for TnitDNAV which infects Thalassiosira nitzschioides, infect various Chaetoceros species. Only a single strain was identified for each virus with two exceptions: 118 CdebDNAV and eight CtenDNAV type I virus clones were isolated and although some of these had different infection ranges against the host strains tested, only CdebDNAV18 and CtenDNAV06 type I were thoroughly characterized. For all of these diatom viruses, infectivity is highly host specific and these viruses infect only a single diatom species, or only certain strains of an individual species. The virions of these ssDNA diatom viruses are icosahedral, $32-38 \mathrm{~nm}$ in diameter, and lack envelopes or tails. The particles assemble in the host nucleus where, interestingly, rod-shaped particles are often also observed (e.g. Kimura and Tomarua, 2015; Tomaru et al., 2011a,b). Whether these rodshaped particles represent a precursor involved in mature virion assembly and/or a co-infecting virus remains unclear.

Viral genomes in this group are composed of both a single molecule of covalently closed, circular ssDNA nucleic acid ca. 5500 to $6000 \mathrm{bp}$ in length and a smaller (600-1000 bp) linear segment of ssDNA; CdebDNAV is an exception and instead harbours a ssDNA genome ca. $7 \mathrm{~kb}$ long with undetermined structure. Interestingly, in each virus the linear segment is complimentary to a region on the closed circle and forms a partially dsDNA region; the genome of CsetDNAV is another exception, however, as it includes eight rather than one complimentary ssDNA segments ranging from 67 to $145 \mathrm{bp}$ in length. The functional significance of the dsDNA viral region remains unclear, although the region may contain an ORF (open reading frame) coding for an unknown protein and has also been suggested to serve as a primer for strand elongation during viral replication. Where determined, viral genomes have at least three ORFs coding for various viral proteins with unknown function (VP1), or are recognizable as a replication protein (VP3), or possibly the viral structural protein (VP2). Burst sizes and latent periods for these viruses vary, ranging from 29.1 infectious units/ cell to $2.2 \times 10^{4}$ infectious units/cell, and from less than 12 to $96 \mathrm{~h}$, respectively (Kimura and Tomarua, 2015). Importantly, since the genetic relationships inferred between these viruses vary depending on 
the viral ORFs used for analysis, the phylogeny among putative bacilladnaviruses is unclear and would benefit from further investigation (Kimura and Tomaru, 2013). Nonetheless, it is clear that all of these viruses are closely related to each other and only distantly related to other known viruses, such as avian circoviruses, and therefore they likely represent distinct taxa within an evolutionarily conserved group of diatom viruses.

\section{RNA viruses}

Historically, research on algal viruses has focused on dsDNA viruses, the earliest isolated algal viruses, but recent work (as described in the section 'Diversity inferred from environmental nucleic acids' above) has demonstrated that RNA viruses are also abundant in marine environments and their impacts on plankton mortality warrant further investigation (Chow and Suttle, 2015, Steward et al., 2013). Currently, MpRV (Brussaard et al., 2004a) remains the only dsRNA algal virus formally recognized by the ICTV, whereas several algal viruses with positive-strand (+)ssRNA genomes have been isolated, including viruses of raphidophyte algae such as HaRNAV (Tai et al., 2003), the dinoflagellate virus HcRNAV (Tomaru et al., 2004a), and various diatom viruses that infect species of Rhizosolenia (Nagasaki et al., 2004), Chaetoceros (Kimura and Tomarua, 2015; Shirai et al., 2008; Tomaru et al., 2009b, 2013a) and Asterionellopsis (Tomaru et al., 2012). Notably, no negative-sense ssRNA viruses infecting eukaryotic algae have been isolated to date.

\section{Double-stranded RNA (dsRNA) viruses}

\section{Mimoreovirus}

Viruses infecting the green alga Micromonas pusilla provided the first evidence for infective algal viruses in seawater (Mayer and Taylor, 1979), and some of the M. pusilla viruses represent the only known dsRNA viruses that infect eukaryotic algae (Brussaard et al., 2004a). M. pusilla is a globally important primary producer throughout the world's oceans, and is a member of the class Prasinophyceae, a primitive chlorophyte that may be ancestral to all other green algae and land plant classes (Martínez Martínez et al., 2015); isolations of viruses infecting this primitive algal host therefore could be important for understanding virus-host interactions over long evolutionary time scales (Brussaard et al., 2004a).

Although most viruses isolated from M. pusilla are members of the family Phycodnaviridae, dsRNA viruses that also infect $M$. pusilla were isolated from coastal waters in Bergen, Norway (Attoui $e t$ al., 2006; Brussaard et al., 2004a). These viruses (MpRV) have small, ca. 90 to $95 \mathrm{~nm}$ diameter, icosahedral virions with thick outer layers surrounding smaller electron-dense inner cores. Viral infectivity is retained following treatment with chloroform suggesting that the virions lack a lipid component. MpRV encodes a 22,563 bp genome composed of 11 linear dsRNA segments ranging in size from $741 \mathrm{bp}$ to 5,792 bp (Attoui et al., 2006; Brussaard et al., 2004a). Genome segments each encode a single ORF except segment 5 , which may encode two related protein products. Hence, the MpRV genome encodes at least 11 protein products. The segmented dsRNA genome of MpRV is characteristic of Reoviridae, a family of viruses that infect a huge range of eukaryote hosts and that have 18,500 to $29,210 \mathrm{bp}$ genomes composed of single copies of 9 to 12 linear dsRNA segments. Reoviridae capsids are non-enveloped, 60 to $100 \mathrm{~nm}$ in diameter, composed of one to concentric protein layers surrounding the genome, and exhibit icosahedral symmetry, all of which are characteristics of MpRV. Additionally, all genomic segments and the putative RNA-dependent RNA-polymerase (RdRp) of MpRV contain, respectively, conserved terminal sequences and the signature motifs of family RdRps, further supporting the notion that MpRV is a member of Reoviridae (Attoui et al., 2006; Brussaard et al., 2004a).

Among other factors, the number of genomic segments distinguishes Reoviridae genera, yet MpRV possesses features unusual among other Reoviridae members including unique termini sequences, an algal host, and an additional, constitutively expressed outer protein coat. These features led to the classification of $\mathrm{MpRV}$ as belonging to a genus of Reoviridae designated Mimoreovirus (Micromonas pusilla reovirus, MpRV). Phylogenetic analysis of MpRV RNA polymerase sequences demonstrated that it does not cluster with any known reoviruses ( $\leq 21 \%$ amino acid identity). Instead, the MpRV branch bisects the Reoviridae 
RdRp phylogenetic tree into the two recognized Reoviridae subfamilies, the Sedoreovirnae within which the Mimoreovirus resides, and the Spinareovirinae. Based on its RdRp phylogeny and the older evolutionary age of $M$. pusilla compared with other Reoviridae hosts, MpRV may represent a third, possibly ancestral, branch of reoviruses (Attoui et al., 2006).

Currently, MpRV is the first and only isolated dsRNA algal virus, thereby demonstrating the need for ongoing isolation efforts to more fully appreciate the diversity of algal viruses. Additionally, the co-occurrence of MpRV in a water sample with larger, 100 to $140 \mathrm{~nm}$ diameter dsDNA viruses that also infect M. pusilla is noteworthy (Brussaard et al., 2004a). Although mechanisms allowing the co-existence of these two viruses infecting the same host remain unclear, the unique latent periods, burst sizes, infectivity of virions produced (the proportion of infectious particles to intact virions), and strategies to prevent superinfection (i.e. simultaneous infection of a single host cell by both MpRV and the dsDNA virus) are likely important factors. Ultimately, future work should investigate the presumed stable co-existence of different viruses infecting the same host to further understanding of the ecology of viruses infecting phytoplankton (Brussaard et al., 2004a).

\section{Single-stranded RNA (ssRNA) viruses}

\section{Marnavirus}

Isolated from the Strait of Georgia, British Columbia, Canada, HaRNAV is a picornavirus (order: Picornavirales; family: Marnaviridae; genus: Marnavirus) that lyses the toxic bloom-forming alga Heterosigma akashiwo and is also the first ssRNA virus isolated that infects phytoplankton (Tai et al., 2003). The host range of HaRNAV was tested using host strains obtained from distant locations such as coastal North America, Japan, and the Northwest Atlantic and demonstrated that the virus has a distinct host range compared with other $H$. akashiwo viruses. The fact that HaRNAV can infect host strains from both North American and Japanese waters suggest that this virus may be widespread in nature, at least within the Pacific Ocean (Tai et al., 2003). Although the original classification of HaRNAV was to an unassigned family, the Marnaviridae, it was recognized as an ssRNA picorna-like virus. Subsequent work on picorna-like viruses led to the eventual creation of the order Picornavirales in 2005 and the inclusion of Marnaviridae as a family with the order (Le Gall et al., 2008).

Infectivity of HaRNAV is host strain specific, and virions are icosahedral, approximately $25 \mathrm{~nm}$ in diameter, lack envelopes or tails, and undergo lytic release. Cytopathic effects such as endoplasmic reticulum swelling begin approximately $48 \mathrm{~h}$ after infection, and the latent period and burst size of HaRNAV are estimated to be $29 \mathrm{~h}$ and $2.1 \times 10^{4}$ viral particles/cell, respectively (Lawrence et al., 2006). HaRNAV houses an approximately $8.6 \mathrm{~kb}$ positive sense ssRNA genome containing a single ORF that is polyadenylated at the $3^{\prime}$ terminus (Lang et al., 2004). Both the 5' and 3' untranslated regions (UTRs) share the same $123 \mathrm{bp}$ sequence and, interestingly, this pair of repeats may facilitate viral RNA replication or polyprotein translation. The HaRNAV polyprotein, in order from 5' to 3', is predicted to have the following protein domains: helicase, protease, RNA-dependent RNA polymerase, and structural viral proteins 2,3 , and 1 . While sequencing of the genome revealed the relation of HaRNAV to viruses from the picorna-like superfamily (now recognized as the order Picornavirales), HaRNAV did not clearly belong to any defined families at the time of isolation. As such, the family Marnaviridae was established within which HaRNAV is currently the only member (Le Gall et al., 2008).

\section{Bacillarnavirus}

Bacillarnavirus is a genus within the Picornavirales that has not yet been assigned to a family. Currently, three virus species are formally recognized within this genus including Rhizosolenia setigera $R N A$ virus 01 (RsetRNAV01), Chaetoceros tenuissimus RNA virus 01 (CtenRNAV01), and Chaetoceros socialis f. radians RNA virus 01 (CsfrRNAV01), but based on phylogenetic relationships of the replicase (i.e. ORF1 or RdRp) or structural protein (ORF2), it appears that the genus should also include the diatom viruses Csp03RNAV that infects Chaetoceros sp. (SS08-C03), AglaRNAV that infects Asterionella glacialis, and CtenRNAV type II that infects Chaetoceros tenuissimus (Kimura and Tomarua, 2015; Tomaru et al., 2013a).

All of these RNA viruses were isolated from water bodies near western Japan and all infect Chaetoceros 
species except RsetRNAV and AglaRNAV, which infect Rhizosolenia setigera and Asterionellopsis glacialis, respectively. Interestingly, all viruses infect centric (radially symmetrical) diatoms except AglaRNAV, which is the first virus isolated that infects a pennate (bilaterally symmetric) diatom (Tomaru et al., 2012). Virions are non-enveloped, non-tailed, icosahedral, approximately 22 to $36 \mathrm{~nm}$ in diameter, and assemble in the cytoplasm. Only a single viral strain was identified for each virus except RsetRNAV, where nine strains (RsetRNAV01-09) were obtained from the original water sample; only strains RsetRNAV01 and RsetRNAV06, however, were further characterized (Nagasaki et al., 2004). The infectivity of most Bacillarnavirus members seems to be highly host strain specific; for instance, unique infectivity spectra were observed for each of the nine RsetRNAV strains isolated when they were tested against 25 strains of $R$. setigera (Nagasaki et al., 2004). One exception is CtenRNAV type II which, unlike CtenRNAV type I (CtenRNAV), lyses four other Chaetoceros species in addition to C. tenuissimus. Virus latent periods are less than $48 \mathrm{~h}$ for CsfrRNAV and Csp03RNAV, less than $24 \mathrm{~h}$ for CtenRNAV type I, 24 to $48 \mathrm{~h}$ for CtenRNAV type II, and $48 \mathrm{~h}$ for RsetRNAV. The burst sizes for RsetRNAV, CtenRNAV type I, CtenRNAV type II, CsfrRNAV, and Csp03RNAV are $3.1 \times 10^{3}, 1.0 \times$ $10^{4}, 287$, and 66 infectious units/cell, and unknown, respectively. Both the latent period and burst size for AglaRNAV have yet to be determined (Kimura and Tomarua, 2015). Bacillarnavirus members have linear, positive ssRNA genomes ranging from 8.4 to $9.6 \mathrm{~kb}$ in length with $3^{\prime}$ poly (A) tails and two ORFs, the first encodes the replicase - which includes the viral RNA helicase and RNA-dependent RNA polymerase - while the second encodes a structural polyprotein (Kimura and Tomarua, 2015; Nagasaki, 2008; Shirai et al., 2006, 2008).

From an ecological perspective, it is interesting to note that at least four distinct virus species, CtenRNAV types I and II as well as CtenDNAV types I and II (see 'ss DNA viruses' above), have been isolated that share the same diatom host, $C$. tenuissimus. Importantly, like Heterosigma akashiwo and its viruses, $C$. tenuissimus and its viruses could serve as an important model system for studies of algal host-virus relationships in order to enhance understanding of competition between viruses and what impact this might have on their host dynamics
(Kimura and Tomarua, 2015). Furthermore, given that several algae such as Micromonas pusilla, Heterosigma akashiwo, and Chaetoceros tenuissimus, for example, are known to be infected by multiple types of viruses, it is easy to speculate that this is a widespread phenomenon in algal ecology, and algal virus research concerning such intra-virus interactions will remain probably in a 'discovery phase' for many years to come.

\section{Dinornavirus}

HcRNAV, a virus that infects the dinoflagellate Heterocapsa circularisquama and was originally isolated from various sites in coastal western Japan, is the first ssRNA dinoflagellate virus isolated and is the only species of the newly established genus and family Dinornavirus and Alvernaviridae. Moreover, the family name Alvernaviridae was chosen to recognize the fact that Dinornavirus was the first virus isolated to infect an Alveolate, a broad group of protozoans that includes ciliates, apicomplexa, and dinoflagellates. HcRNAV is a tailless icosahedron particle approximately $30 \mathrm{~nm}$ in diameter that lacks an external membrane and replicates in the host cytoplasm by forming crystalline arrays or unordered aggregations. The latent period and burst size of HcRNAV are estimated to be 24 to $48 \mathrm{~h}$ and $3.4 \times 10^{3}$ to $2.1 \times 10^{4}$ infectious units/cell. The virus harbours a +ssRNA genome that is approximately $4.4 \mathrm{~kb}$ in size, lacks a 3 ' poly(A) tail (instead having a 3 ' stem-loop structure), and contains two ORFs: ORF-1 encodes a polyprotein containing protease and RNA-dependent RNA polymerase domains, while ORF-2 encodes a capsid protein gene within which four variable regions are present that determine strain-specific infectivity (Nagasaki et al., 2005a).

More than $100 \mathrm{HcRNAV}$ virus strains were isolated using four $H$. circularisquama host strains (HU9433-P, HA92-1, HCLG-1, or HY9423) and, after testing their infection spectra against 56 different host strains, were ultimately classified into two virus types, $\mathrm{CY}$ and $\mathrm{UA}$, depending on whether they were isolated using either of the HCLG-1 and HY9423, or HU9433-P and HA92-1 host strain pairs, respectively. These viruses were also used to challenge 32 other algal species belonging to the families Bacillariophyceae, Chlorophyceae, Dinophyceae, Euglenophyceae, Eustigmatophyceae, and Raphidophyceae, but no infection was observed 
for any alga besides $H$. circularisquama (Tomaru et al., 2004a). Strains HcRNAV34 (type CY) and HcRNAV109 (type UA) were further characterized demonstrating that these two viruses were $97.0 \%$ similar with respect to their nucleotide sequences, and also demonstrated their complimentary, non-overlapping host strain-specificity (Nagasaki et al., 2005a). Interestingly, the co-existence of many distinct virus and host strains in a particular geographic region suggests that HcRNAV can influence the population dynamics of $H$. circularisquama in terms of both biomass and strain composition (Tomaru et al., 2007). How these two distinct virus types evolved, were selected for, and can stably coexist with each other as well as with $\mathrm{HcV}$, a dsDNA virus also infecting $H$. circularisquama (see 'dsDNA viruses' above) remains unclear, however, and warrants further study (Tomaru et al., 2007).

\section{Genome classification unknown}

Several eukaryotic algal viruses with unknown or unverified genome types, none of which have been classified by the ICTV, have been isolated and partially characterized. These include the nuclear inclusion viruses CspNIV (Bettarel et al., 2005), CwNIV (Eissler et al., 2009) and HaNIV (Lawrence et al., 2001), as well as the diatom viruses $S \cos V$ (Kim et al., 2015a) and SpalV (Kim et al., 2015b), and the virus TampV (Nagasaki et al., 2009) which infects a Cryptophyte alga.

The nuclear inclusion viruses CspNIV, CwNIV, and $\mathrm{HaNIV}$ are all characterized by small virus particle sizes (approximately $20-30 \mathrm{~nm}$ in diameter), viral replication within the nucleoplasm of their host cells, and formation of crystalline or paracrystalline arrays of virus-like particles during infection. Both CspNIV and CwNIV were isolated from the Chesapeake Bay, USA and lyse the diatoms Chaetoceros $\mathrm{cf}$. gracilis and Chaetoceros cf. Wighamii, respectively (Bettarel et al., 2005; Eissler et al., 2009). Infectivity of the viruses appears to be specific to these species, although strain-specificity is unknown. HaNIV was isolated from coastal British Columbia, Canada and lyses the Raphidophyte Heterosigma akashiwo (Lawrence et al., 2001). Infectivity is host-specific, lysing some strains of $H$. akashiwo but not others. All three viruses are icosahedral, although in the case of CwNIV-infected cells, virus-like particles are also observed in a rod-like structural arrangement. It has been suggested that CwNIV virus maturation involves the formation of such rod-like structures (observed in cross-section as paracrystalline arrays) which fragment to produce free virus particles (as no paracrystalline structures have been observed in lysates), although it is also possible that two different viruses may instead co-infect the same cell. The latent periods for CspNIV and CwNIV are estimated to be less than 24 and $8 \mathrm{~h}$, respectively. The burst size for CwNIV is estimated to be approximately $2.64 \times 10^{4}$ viruses/cell.

$\mathrm{S} \operatorname{cosV}$ and SpalV are diatom viruses, isolated from Jaran Bay, Korea, which lyse Skeletonema costatum and Stephanopyxis palmeriana, respectively (Kim et al., 2015a; 2015b). Infectivity appears to be strain-specific for $\mathrm{ScosV}$ and species-specific for SpalV (though strain-specificity has not been tested). While $\mathrm{S} \cos V$ is icosahedral in shape (hexagonal in outline) and approximately 40 to $50 \mathrm{~nm}$ in diameter, SpalV is round-shaped and only 20 to $30 \mathrm{~nm}$ in diameter. Both viruses propagate in the cytoplasm of their host, form no crystalline arrays, and have no visible outer membrane or tail-like structure. The latent periods for ScosV and SpalV are estimated to be less than 48 and $80 \mathrm{~h}$, respectively, while their burst sizes are estimated to be approximately 90 to 250 and 92 infectious units/ cell, respectively.

TampV is a Cryptophyte virus, isolated from the Yasushiro Sea in Japan, which lyses Teleaulax amphioxeia (Nagasaki et al., 2009). It is approximately $203 \mathrm{~nm}$ in diameter, icosahedral in shape, and its infectivity appears to be strain-specific. The virus propagates in the cytoplasm of its host, forms no crystalline arrays, and has no visible outer membrane or tail-like structure. The latent period for the virus was estimated to be less than $24 \mathrm{~h}$, while its burst size was estimated at approximately 430 to 530 infectious units/cell (though it has also been estimated that there may be upwards of 760 virus particles within an infected cell). It is thought that TampV harbours a dsDNA genome, although this has not yet been confirmed.

\section{Summary}

Clearly, our knowledge of algal viruses has expanded rapidly over the last few decades. We have come a long way since the discovery and isolation of the dsDNA viruses that infect Chlorellalike algae and that led to the establishment of the 
prominent algal virus family, the Phycodnaviridae. Currently, dsDNA, ssDNA, dsRNA, and ssRNA viruses that infect a diverse array of algae have been isolated. Although there are a few notable exceptions, the vast majority of these algal pathogens are lytic viruses that are highly species or strain specific. We must be cautious, however, when drawing such broad conclusions, as strain-specificity tests cannot be exhaustive, and environmental conditions that promote latent infections may not be adequately mimicked under laboratory conditions. Nonetheless, due to the dedicated research efforts of the many individuals cited herein, we have come to appreciate that algal viruses are a diverse, dynamic, and ecologically important part of the biosphere. Whether only a few, many, or all species of algae are susceptible to one or more viral infections is impossible to know at this stage of research. Whatever the case, it can be assumed that many viruses await discovery and characterization, and it is undoubtable that the world of algal virus research will bring many more surprises. As active, major participants in the Earth's biogeochemical cycles, knowledge of the major aquatic primary producers (i.e. algae) is critical for our understanding of the living planet we inhabit. By extension, and based on the knowledge that diverse algae are infected by diverse viruses, knowing and understanding the viruses that infect algae is a vitally important scientific endeavour that reaches beyond the aquatic sciences.

\section{References}

Abergel, C., Legendre, M., and Claverie, J.M. (2015). The rapidly expanding universe of giant viruses: mimivirus, pandoravirus, pithovirus and mollivirus. FEMS Microbiol. Rev. 39, 779-796. https://doi.org/10.1093/ femsre/fuv037.

Allen, M.J., Schroeder, D.C., Donkin, A., Crawfurd, K.J., and Wilson, W.H. (2006a). Genome comparison of two coccolithoviruses. Virol. J. 3, 15.

Allen, M.J., Schroeder, D.C., Holden, M.T., and Wilson, W.H. (2006b). Evolutionary history of the Coccolithoviridae. Mol. Biol. Evol. 23, 86-92.

Angly, F.E., Felts, B., Breitbart, M., Salamon, P., Edwards, R.A., Carlson, C., Chan, A.M., Haynes, M., Kelley, S., Liu, H., et al. (2006). The marine viromes of four oceanic regions. PLOS Biol. 4, e368.

Arslan, D., Legendre, M., Seltzer, V., Abergel, C., and Claverie, J.M. (2011). Distant Mimivirus relative with a larger genome highlights the fundamental features of Megaviridae. Proc. Natl. Acad. Sci. U.S.A. 108, 1748617491. https://doi.org/10.1073/pnas.1110889108.

Attoui, H., Jaafar, F.M., Belhouchet, M., de Micco, P., de Lamballerie, X., and Brussaard, C.P.D. (2006). Micromonas pusilla reovirus: a new member of the family Reoviridae assigned to a novel proposed genus (Mimoreovirus). J. Gen. Virol. 87, 1375-1383.

Baltimore, D. (1971). Expression of animal virus genomes. Bacteriol. Rev. 35, 235-241.

Baudoux, A.C., and Brussaard, C.P. (2005). Characterization of different viruses infecting the marine harmful algal bloom species Phaeocystis globosa. Virology 341, 80-90.

Bellec, L., Grimsley, N., and Desdevises, Y. (2010). Isolation of prasinoviruses of the green unicellular algae Ostreococcus spp. on a worldwide geographical scale. Appl. Environ. Microbiol. 76, 96-101. https://doi. org/10.1128/AEM.01799-09.

Bellec, L., Grimsley, N., Moreau, H., and Desdevises, Y. (2009). Phylogenetic analysis of new Prasinoviruses (Phycodnaviridae) that infect the green unicellular algae Ostreococcus, Bathycoccus and Micromonas. Environ Microbiol. Rep. 1, 114-123. https://doi.org/10.1111/ j.1758-2229.2009.00015.x.

Bench, S.R., Hanson, T.E., Williamson, K.E., Ghosh, D., Radosovich, M., Wang, K., and Wommack, K.E. (2007). Metagenomic characterization of Chesapeake Bay virioplankton. Appl. Environ. Microbiol. 73, 7629-7641.

Bergh, O., Børsheim, K.Y., Bratbak, G., and Heldal, M. (1989). High abundance of viruses found in aquatic environments. Nature 340, 467-468. https://doi. org/10.1038/340467a0.

Bettarel, Y., Kan, J., Wang, K., Williamson, K.E., Cooney, S., Ribblett, S., Chen, F., Wommack, K.E., and Coats, D.W. (2005). Isolation and preliminary characterisation of a small nuclear inclusion virus infecting the diatom Chaetoceros cf. gracilis. Aquat. Microb. Ecol. 40, 103-114.

Bratbak, G., Egge,J.K., and Heldal, M. (1993). Viral mortality of the marine alga Emiliania huxleyi (Haptophyceae) and termination of algal blooms. Mar. Ecol. Prog. Ser. 93, 39-48.

Breitbart, M., Felts, B., Kelley, S., Mahaffy, J.M., Nulton, J., Salamon, P., and Rohwer, F. (2004). Diversity and population structure of a near-shore marine-sediment viral community. Proc. Biol. Sci. 271, 565-574. https:// doi.org/10.1098/rspb.2003.2628.

Breitbart, M., Salamon, P., Andresen, B., Mahaffy, J.M., Segall, A.M., Mead, D., Azam, F., and Rohwer, F. (2002). Genomic analysis of uncultured marine viral communities. Proc. Natl. Acad. Sci. U.S.A. 99, 1425014255. https://doi.org/10.1073/pnas.202488399.

Breitbart, M., Thompson, L.R., Suttle, C.A., and Sullivan, M.B. (2007). Exploring the vast diversity of marine viruses. Oceanography 20, 135-139.

Brodie, J., and Lewis, J., eds. (2007). Unravelling the algae: the past, present, and future of algal systematics (CRC Press, Boca Raton).

Brussaard, C.P. (2004). Viral control of phytoplankton populations - a review. J. Eukaryot. Microbiol. 51, 125-138.

Brussaard, C.P.D., and Martínez Martínez, J. (2008). Algal bloom viruses. Plant Viruses 2, 1-13.

Brussaard, C.P., Noordeloos, A.A., Sandaa, R.A., Heldal, M., and Bratbak, G. (2004a). Discovery of a dsRNA virus infecting the marine photosynthetic protist Micromonas pusilla. Virology 319, 280-291. https://doi. org/10.1016/j.virol.2003.10.033. 
Brussaard, C.P., Short, S.M., Frederickson, C.M., and Suttle, C.A. (2004b). Isolation and phylogenetic analysis of novel viruses infecting the phytoplankton Phaeocystis globosa (Prymnesiophyceae). Appl. Environ. Microbiol. 70, 3700-3705. https://doi.org/10.1128/ AEM.70.6.3700-3705.2004.

Bubeck, J.A., and Pfitzner, A.J.P. (2005). Isolation and characterization of a new type of chlorovirus that infects an endosymblotic Chlorella strain of the heliozoon Acanthocystis turfacea. J. Gen. Virol. 86, 2871-2877.

Castberg, T., Thyrhaug, R., Larsen, A., Sandaa, R.A., Heldal, M., Van Etten, J.L., and Bratbak, G. (2002). Isolation and characterization of a virus that infects Emiliania huxleyi (Haptophyta). J. Phycol. 38, 767-774.

Charlson, R.J., Lovelock, J.E., Andreae, M.O., and Warren, S.G. (1987). Oceanic phytoplankton, atmospheric sulfur, cloud albedo and climate. Nature 326, 655-661.

Chen, F., and Suttle, C.A. (1995). Amplification of DNA polymerase gene fragments from viruses infecting microalgae. Appl. Environ. Microbiol. 61, 1274-1278.

Chen, F., and Suttle, C.A. (1996). Evolutionary relationships among large double-stranded DNA viruses that infect microalgae and other organisms as inferred from DNA polymerase genes. Virology 219, 170-178.

Chen, F., Suttle, C.A., and Short, S.M. (1996). Genetic diversity in marine algal virus communities as revealed by sequence analysis of DNA polymerase genes. Appl. Environ. Microbiol. 62, 2869-2874.

Chow, C.E., and Suttle, C.A. (2015). Biogeography of viruses in the sea. Annu. Rev. Virol. 2, 41-66. https:// doi.org/10.1146/annurev-virology-031413-085540.

Chow, C.E., Winget, D.M., White, R.A., Hallam, S.J., and Suttle, C.A. (2015). Combining genomic sequencing methods to explore viral diversity and reveal potential virus-host interactions. Front. Microbiol. 6, 265. https://doi.org/10.3389/fmicb.2015.00265.

Clasen, J.L., and Suttle, C.A. (2009). Identification of freshwater Phycodnaviridae and their potential phytoplankton hosts, using DNA pol sequence fragments and a genetic-distance analysis. Appl. Environ. Microbiol. 75, 991-997. https://doi.org/10.1128/ AEM.02024-08.

Claverie, J.M., and Abergel, C. (2009). Mimivirus and its virophage. Annu. Rev. Genet. 43, 49-66. https://doi. org/10.1146/annurev-genet-102108-134255.

Clerissi, C., Desdevises, Y., and Grimsley, N. (2012). Prasinoviruses of the marine green alga Ostreococcus tauri are mainly species specific. J. Virol. 86, 4611-4619. https://doi.org/10.1128/JVI.07221-11.

Clerissi, C., Desdevises, Y., Romac, S., Audic, S., de Vargas, C., Acinas, S.G., Casotti, R., Poulain, J., Wincker, P., Hingamp, P., et al. (2015). Deep sequencing of amplified Prasinovirus and host green algal genes from an Indian Ocean transect reveals interacting trophic dependencies and new genotypes. Environ Microbiol Rep 7, 979-989. https://doi.org/10.1111/1758-2229.12345.

Clerissi, C., Grimsley, N., Ogata, H., Hingamp, P., Poulain, J., and Desdevises, Y. (2014). Unveiling of the diversity of Prasinoviruses (Phycodnaviridae) in marine samples by using high-throughput sequencing analyses of PCRamplified DNA polymerase and major capsid protein genes. Appl. Environ. Microbiol. 80, 3150-3160. https://doi.org/10.1128/AEM.00123-14.
Colson, P., De Lamballerie, X., Yutin, N., Asgari, S., Bigot, Y., Bideshi, D.K., Cheng, X.W., Federici, B.A., Van Etten, J.L., Koonin, E.V., et al. (2013). 'Megavirales', a proposed new order for eukaryotic nucleocytoplasmic large DNA viruses. Arch. Virol. 158, 2517-2521. https://doi. org/10.1007/s00705-013-1768-6.

Correa, A.M., Ainsworth, T.D., Rosales, S.M., Thurber, A.R., Butler, C.R., and Vega Thurber, R.L. (2016). Viral outbreak in corals associated with an in situ bleaching event: atypical herpes-like viruses and a new megavirus infecting Symbiodinium. Front. Microbiol. 7, 127. https://doi.org/10.3389/fmicb.2016.00127.

Correa, A.M., Welsh, R.M., and Vega Thurber, R.L. (2013). Unique nucleocytoplasmic dsDNA and +ssRNA viruses are associated with the dinoflagellate endosymbionts of corals. ISME J. 7, 13-27. https://doi.org/10.1038/ ismej.2012.75.

Cottrell, M.T., and Suttle, C.A. (1991). Wide-spread occurrence and clonal variation in viruses which cause lysis of a cosmopolitan, eukaryotic marine phytoplankter, Micromonas pusilla. Mar. Ecol. Prog. Ser. 78, 1-9.

Culley, A.I., Asuncion, B.F., and Steward, G.F. (2009). Detection of inteins among diverse DNA polymerase genes of uncultivated members of the Phycodnaviridae. ISME J. 3, 409-418. https://doi.org/10.1038/ ismej.2008.120.

Culley, A.I., Lang, A.S., and Suttle, C.A. (2003). High diversity of unknown picorna-like viruses in the sea. Nature 424, 1054-1057. https://doi.org/10.1038/ nature 01886

Culley, A.I., Lang, A.S., and Suttle, C.A. (2006). Metagenomic analysis of coastal RNA virus communities. Science 312, 1795-1798.

Culley, A.I., Mueller, J.A., Belcaid, M., Wood-Charlson, E.M., Poisson, G., and Steward, G.F. (2014). The characterization of RNA viruses in tropical seawater using targeted PCR and metagenomics. MBio 5, e01210-14. https://doi.org/10.1128/mBio.01210-14.

Culley, A.I., and Steward, G.F. (2007). New genera of RNA viruses in subtropical seawater, inferred from polymerase gene sequences. Appl. Environ. Microbiol. 73, 5937-5944.

Delaroque, N., Boland, W., Müller, D.G., and Knippers, R. (2003). Comparisons of two large phaeoviral genomes and evolutionary implications. J. Mol. Evol. 57, 613-622. https://doi.org/10.1007/s00239-003-2501-y.

Delaroque, N., Müller, D.G., Bothe, G., Pohl, T., Knippers, R., and Boland, W. (2001). The complete DNA sequence of the Ectocarpus siliculosus virus EsV-1 genome. Virology 287, 112-132. https://doi.org/10.1006/ viro.2001.1028.

Derelle, E., Ferraz, C., Escande, M.L., Eychenié, S., Cooke, R., Piganeau, G., Desdevises, Y., Bellec, L., Moreau, H., and Grimsley, N. (2008). Life-cycle and genome of OtV5, a large DNA virus of the pelagic marine unicellular green alga Ostreococcus tauri. PLOS ONE 3, e2250. https:// doi.org/10.1371/journal.pone.0002250.

Dunigan, D.D., Fitzgerald, L.A., and Van Etten, J.L. (2006). Phycodnaviruses: a peek at genetic diversity. Virus Res. $117,119-132$.

Edwards, R.A., and Rohwer, F. (2005). Viral metagenomics. Nat. Rev. Microbiol. 3, 504-510. 


\section{Short et al.}

Eissler, Y., Wang, K., Chen, F., Eric Wommack, K., and Wayne Coats, D. (2009). Ultrastructural characterization of the lytic cycle of an intranuclear virus infecting the diatom Chaetoceros Cf. Wighamii (Bacillariophyceae) from Chesapeake Bay, USA(1). J. Phycol. 45, 787-797. https://doi.org/10.1111/j.1529-8817.2009.00705.x.

Fancello, L., Trape, S., Robert, C., Boyer, M., Popgeorgiev, N., Raoult, D., and Desnues, C. (2013). Viruses in the desert: a metagenomic survey of viral communities in four perennial ponds of the Mauritanian Sahara. ISME J. 7, 359-369. https://doi.org/10.1038/ismej.2012.101.

Fischer, M.G. (2016). Giant viruses come of age. Curr. Opin. Microbiol. 31, 50-57.

Fischer, M.G., and Suttle, C.A. (2011). A virophage at the origin of large DNA transposons. Science 332, 231-234. https://doi.org/10.1126/science.1199412.

Fitzgerald, L.A., Graves, M.V., Li, X., Feldblyum, T., Hartigan, J., and Van Etten, J.L. (2007a). Sequence and annotation of the 314-kb MT325 and the 321-kb FR483 viruses that infect Chlorella Pbi. Virology 358, 459-471.

Fitzgerald, L.A., Graves, M.V., Li, X., Feldblyum, T., Nierman, W.C., and Van Etten, J.L. (2007b). Sequence and annotation of the 369-kb NY-2A and the 345-kb AR158 viruses that infect Chlorella NC64A. Virology $358,472-484$.

Fitzgerald, L.A., Graves, M.V., Li, X., Hartigan, J., Pfitzner, A.J., Hoffart, E., and Van Etten, J.L. (2007c). Sequence and annotation of the 288-kb ATCV-1 virus that infects an endosymbiotic chlorella strain of the heliozoon Acanthocystis turfacea. Virology 362, 350-361.

Frada, M., Probert, I., Allen, M.J., Wilson, W.H., and de Vargas, C. (2008). The 'Cheshire Cat' escape strategy of the coccolithophore Emiliania huxleyi in response to viral infection. Proc. Natl. Acad. Sci. U.S.A. 105, 1594415949. https://doi.org/10.1073/pnas.0807707105.

Franklin, D.J., Steinke, M., Young, J., Probert, I., and Malin, G. (2010). Dimethylsulphoniopropionate (DMSP), DMSP-lyase activity (DLA) and dimethylsulphide (DMS) in 10 species of coccolithophore. Mar. Ecol. Prog. Ser. 410, 13-23.

Friess-Klebl, A.K., Knippers, R., and Muller, D.G. (1994). Isolation and characterization of a DA virus infecting Feldmannia simplex (Phaeophyceae). J. Phycol. 30, 653-658.

Ghedin, E., and Claverie, J.M. (2005). Mimivirus relatives in the Sargasso sea. Virol. J. 2, 62.

Green, J.C., Rahman, F., Saxton, M.A., and Williamson, K.E. (2015). Metagenomic assessment of viral diversity in Lake Matoaka, a temperate, eutrophic freshwater lake in Southeastern Virginia, USA. Aquat. Microb. Ecol. 75, $117-128$.

Guiry, M.D. (2012). How many species of algae are there? J. Phycol. 48, 1057-1063. https://doi.org/10.1111/ j.1529-8817.2012.01222.x.

Hallegraeff, G.M., and Hara, Y. (2004). Taxonomy of harmful marine raphidophytes. In Manual on Harmful Marine Microalgae, Hallegraeff, G.M., Anderson, D.M., and Cembella, A.D., eds. (UNESCO Publishing, Paris), p. 793.

Henry, E.C., and Meints, R.H. (1992). A persistent virusinfection in Feldmannia (Phaeophyceae). J. Phycol. 28, $517-26$.
Hingamp, P., Grimsley, N., Acinas, S.G., Clerissi, C., Subirana, L., Poulain, J., Ferrera, I., Sarmento, H., Villar, E., Lima-Mendez, G., et al. (2013). Exploring nucleocytoplasmic large DNA viruses in Tara Oceans microbial metagenomes. ISME J. 7, 1678-1695. https://doi. org/10.1038/ismej.2013.59.

Holligan, P.M., Fernandez, E., Aiken, J., Balch, W.M., Boyd, P., Burkill, P.H., Finch, M., Groom, S.B., Malin, G., Muller, K., et al. (1993). A biogeochemical study of the coccolithophore, Emiliania huxleyi, in the North Atlantic. Global Biogeochem. Cycles 7, 879-900.

Hyman, P.H. and Abedon, S.T. (2018). Viruses of Microorganisms (Norfolk, UK: Caister Academic Press). https://doi.org/10.21775/9781910190852

Iyer, L.M., Aravind, L., and Koonin, E.V. (2001). Common origin of four diverse families of large eukaryotic DNA viruses. J. Virol. 75, 11720-11734. https://doi. org/10.1128/JVI.75.23.11720-11734.2001.

Iyer, L.M., Balaji, S., Koonin, E.V., and Aravind, L. (2006). Evolutionary genomics of nucleo-cytoplasmic large DNA viruses. Virus Res. 117, 156-184.

Jacobsen, A., Bratbak, G., and Heldal, M. (1996). Isolation and characterization of a virus infecting Phaeocystis pouchetii (Prymnesiophyceae). J. Phycol. 32, 923-927.

Jeanniard, A., Dunigan, D.D., Gurnon, J.R., Agarkova, I.V., Kang, M., Vitek, J., Duncan, G., McClung, O.W., Larsen, M., Claverie, J.M., et al. (2013). Towards defining the chloroviruses: a genomic journey through a genus of large DNA viruses. BMC Genomics 14, 158. https:// doi.org/10.1186/1471-2164-14-158.

Johannessen, T.V., Bratbak, G., Larsen, A., Ogata, H., Egge, E.S., Edvardsen, B., Eikrem, W., and Sandaa, R.A. (2015). Characterisation of three novel giant viruses reveals huge diversity among viruses infecting Prymnesiales (Haptophyta). Virology 476, 180-188. https://doi.org/10.1016/j.virol.2014.12.014.

Kang, M., Dunigan, D.D., and van Etten, J.L. (2005). Chlorovirus: a genus of Phycodnaviridae that infects certain chlorella-like green algae. Mol. Plant Pathol. 6, 213-224. https://doi.org/10.1111/j.13643703.2005.00281.x.

Kapp, M., Knippers, R., and Muller, D.G. (1997). New members of a group of DNA viruses infecting brown algae. Phycol. Res. 45, 85-90.

Kim, J., Kim, C.H., Takano, Y., Jang, I.K., Kim, S.W., and Choi, T.J. (2012). Isolation and physiological characterization of a new algicidal virus infecting the harmful dinoflagellate Heterocapsa pygmaea. Plant. Pathol. J. 28, 433-438.

Kim, J., Kim, C.H., Youn, S.H., and Choi, T.J. (2015a). Isolation and physiological characterization of a novel algicidal virus infecting the marine diatom Skeletonema costatum. Plant Pathol. J. 31, 186-191. https://doi. org/10.5423/PPJ.NT.03.2015.0029.

Kim, J., Yoon, S.H., and Choi, T.J. (2015b). Isolation and physiological characterization of a novel virus infecting Stephanopyxis palmeriana (Bacillariophyta). Algae 30, 81-87.

Kimura, K., and Tomaru, Y. (2013). Isolation and characterization of a single-stranded DNA virus infecting the marine diatom Chaetoceros sp. strain SS62811 isolated from western Japan. PLOS ONE 8, e82013. https://doi.org/10.1371/journal.pone.0082013.

Kimura, K., and Tomaru, Y. (2015). Discovery of two novel viruses expands the diversity of single-stranded DNA and single-stranded RNA viruses infecting a 
cosmopolitan marine diatom. Appl. Environ. Microbiol. 81, 1120-1131. https://doi.org/10.1128/AEM.0238014.

King, A.M.Q. Adams, M.J., Carstens, E.B., and Lefkowitz, E.J., eds. (2012). Virus Taxonomy: Classification and Nomenclature of Viruses: Ninth Report of the International Committee on Taxonomy of Viruses (Elsevier Academic Press, San Diego).

Kristensen, D.M., Mushegian, A.R., Dolja, V.V., and Koonin, E.V. (2010). New dimensions of the virus world discovered through metagenomics. Trends Microbiol. 18, 11-19. https://doi.org/10.1016/j.tim.2009.11.003.

La Scola, B., Audic, S., Robert, C., Jungang, L., de Lamballerie, X., Drancourt, M., Birtles, R., Claverie, J.M., and Raoult, D. (2003). A giant virus in amoebae. Science 299, 2033-2033.

La Scola, B., Desnues, C., Pagnier, I., Robert, C., Barrassi, L., Fournous, G., Merchat, M., Suzan-Monti, M., Forterre, P., Koonin, E., et al. (2008). The virophage as a unique parasite of the giant mimivirus. Nature 455, 100-104. https://doi.org/10.1038/nature07218.

Lang, A.S., Culley, A.I., and Suttle, C.A. (2004). Genome sequence and characterization of a virus (HaRNAV) related to picorna-like viruses that infects the marine toxic bloom-forming alga Heterosigma akashiwo. Virology 320, 206-217. https://doi.org/10.1016/j. virol.2003.10.015.

Lanka, S.T.J., Klein, M., Ramsperger, U., Muller, D.G., and Knippers, R. (1993). Genome structure of a virus infecting the marine brown alga Ectocarpus siliculosus. Virology 193, 802-11.

Larsen, J.B., Larsen, A., Bratbak, G., and Sandaa, R.A. (2008). Phylogenetic analysis of members of the Phycodnaviridae virus family, using amplified fragments of the major capsid protein gene. Appl. Environ. Microbiol. 74, 3048-3057. https://doi.org/10.1128/ AEM.02548-07.

Lawrence, J.E., Brussaard, C.P., and Suttle, C.A. (2006). Virus-specific responses of Heterosigma akashiwo to infection. Appl. Environ. Microbiol. 72, 7829-7834.

Lawrence, J.E., Chan, A.M., and Suttle, C.A. (2001). A novel virus (HaNIV) causes lysis of the toxic bloom-forming alga Heterosigma akashiwo (Raphidophyceae). J. Phycol. 37, 216-222.

Lawrence, J.E., Chan, A.M., and Suttle, C.A. (2002). Viruses causing lysis of the toxic bloom-forming alga Heterosigma akashiwo (Raphidophyceae) are widespread in coastal sediments of British Columbia, Canada. Limnol. Oceanogr. 47, 545-550.

Lawrence, S.A., Wilson, W.H., Davy, J.E., and Davy, S.K. (2014). Latent virus-like infections are present in a diverse range of Symbiodinium spp. (Dinophyta). J. Phycol. 50, 984-997. https://doi.org/10.1111/ jpy. 12242.

Le Gall, O., Christian, P., Fauquet, C.M., King, A.M., Knowles, N.J., Nakashima, N., Stanway, G., and Gorbalenya, A.E. (2008). Picornavirales, a proposed order of positive-sense single-stranded RNA viruses with a pseudo-T $=3$ virion architecture. Arch. Virol. 153, 715-727. https://doi.org/10.1007/s00705-0080041-x.

Li, Y., Lu, Z., Sun, L., Ropp, S., Kutish, G.F., Rock, D.L., and Van Etten, J.L. (1997). Analysis of 74 kb of DNA located at the right end of the $330-\mathrm{kb}$ chlorella virus PBCV-1 genome. Virology 237, 360-377.

Littman, R., Willis, B.L., and Bourne, D.G. (2011). Metagenomic analysis of the coral holobiont during a natural bleaching event on the Great Barrier Reef. Environ. Microbiol. Rep. 3, 651-660. https://doi. org/10.1111/j.1758-2229.2010.00234.x.

López-Bueno, A., Tamames, J., Velázquez, D., Moya, A., Quesada, A., and Alcamí, A. (2009). High diversity of the viral community from an Antarctic lake. Science 326, 858-861. https://doi.org/10.1126/science.1179287.

Maier, I., Wolf, S., Delaroque, N., Muller, D.G., and Kawai, H. (1998). A DNA virus infecting the marine brown alga Pilayella littoralis (Ectocarpales, Phaeophyceae) in culture. Eur. J. Phycol. 33, 213-220.

Manrique, J.M., Calvo, A.Y., and Jones, L.R. (2012). Phylogenetic analysis of Ostreococcus virus sequences from the Patagonian Coast. Virus Genes 45, 316-326. https://doi.org/10.1007/s11262-012-0762-5.

Marhaver, K.L., Edwards, R.A., and Rohwer, F. (2008). Viral communities associated with healthy and bleaching corals. Environ. Microbiol. 10, 2277-2286. https://doi. org/10.1111/j.1462-2920.2008.01652.x.

Martínez Martínez, J., Boere, A., Gilg, L., van Lent, J.W.M., Witte, H.J., van Bleijswijk, J.D.L., and Brussaard, C.P.D. (2015). New lipid envelope-containing dsDNA virus isolates infecting Micromonas pusilla reveal a separate phylogenetic group. Aquat. Microb. Ecol. 74, 17-28.

Martínez Martínez, J., Schroeder, D.C., Larsen, A., Bratbak, G., and Wilson, W.H. (2007). Molecular dynamics of Emiliania huxleyi and cooccurring viruses during two separate mesocosm studies. Appl. Environ. Microbiol. 73, 554-562.

Martínez Martínez, J., Swan, B.K., and Wilson, W.H. (2014). Marine viruses, a genetic reservoir revealed by targeted viromics. ISME J. 8, 1079-1088. https://doi. org/10.1038/ismej.2013.214.

Mayer, J.A., and Taylor, F.J.R. (1979). A virus which lyses the marine nanoflagellate Micromonas pusilla. Nature 281, 299-301.

Meints, R.H., Van Etten, J.L., Kuczmarski, D., Lee, K., and Ang, B. (1981). Viral infection of the symbiotic chlorella-like alga present in Hydra viridis. Virology 113, 698-703.

Milligan, K.L.D., and Cosper, E.M. (1994). Isolation of virus capable of lysing the brown tide microalga, Aureococcus anophagefferens. Science 266, 805-7.

Mirza, S.F., Staniewski, M.A., Short, C.M., Long, A.M., Chaban, Y.V., and Short, S.M. (2015). Isolation and characterization of a virus infecting the freshwater algae Chrysochromulina parva. Virology 486, 105-115. https://doi.org/10.1016/j.virol.2015.09.005.

Mokili, J.L., Rohwer, F., and Dutilh, B.E. (2012). Metagenomics and future perspectives in virus discovery. Curr. Opin. Virol. 2, 63-77. https://doi.org/10.1016/j. coviro.2011.12.004.

Monier, A., Claverie, J.M., and Ogata, H. (2008a). Taxonomic distribution of large DNA viruses in the sea. Genome Biol. 9, R106. https://doi.org/10.1186/ gb-2008-9-7-r106.

Monier, A., Larsen, J.B., Sandaa, R.A., Bratbak, G., Claverie, J.M., and Ogata, H. (2008b). Marine mimivirus relatives 
are probably large algal viruses. Virol. J. 5, 12. https:// doi.org/10.1186/1743-422X-5-12.

Moniruzzaman, M., Gann, E.R., LeCleir, G.R., Kang, Y., Gobler, C.J., and Wilhelm, S.W. (2016). Diversity and dynamics of algal Megaviridae members during a harmful brown tide caused by the pelagophyte, Aureococcus anophagefferens. FEMS Microbiol. Ecol. 92, fiw058. https://doi.org/10.1093/femsec/fiw058.

Moniruzzaman, M., LeCleir, G.R., Brown, C.M., Gobler, C.J., Bidle, K.D., Wilson, W.H., and Wilhelm, S.W. (2014). Genome of brown tide virus (AaV), the little giant of the Megaviridae, elucidates NCLDV genome expansion and host-virus coevolution. Virology 466-467, 60-70. https://doi.org/10.1016/j.virol.2014.06.031.

Müller, D.G. (1991). Mendelian segregation of a virus genome during host meiosis in the marine brown alga Ectocarpus siliculosus. J. Plant. Physiol. 137, 739-743.

Müller, D.G. (1992). Intergeneric transmission of a marine plant DNA virus. Naturwissenschaften 79, 37-39.

Müller, D.G., and Parodi, E. (1993). Transfer of a marine DNA virus from Ectocarpus to Feldmannia (Ectocarpales, Phaeophyceae): aberrant symptoms and restitution of the host. Protoplasma 175, 121-125.

Müller, D.G., Sengco, M., Wolf, S., Bräutigam, M., Schmid, C.E., Kapp, M., and Knippers, R. (1996). Comparison of two DNA viruses infecting the marine brown algae Ectocarpus siliculosus and E. fasciculatus. J. Gen. Virol. 77, 2329-2333. https://doi.org/10.1099/0022-1317-77-92329.

Nagasaki, K. (2008). Dinoflagellates, diatoms, and their viruses. J. Microbiol. 46, 235-243. https://doi. org/10.1007/s12275-008-0098-y.

Nagasaki, K., Ando, M., Imai, I., Itakura, S., and Ishida, Y. (1994a). Virus-like particles in Heterosigma akashiwo (Raphidophyceae) - a possible red tide disintegration mechanism. Mar. Biol. 119, 307-312.

Nagasaki, K., Ando, M., Itakura, S., Imai, I., and Ishida, Y. (1994b). Viral mortality in the final stage of Heterosigma akashiwo (Raphidophyceae) red tide. J. Plankton. Res. 16, 1595-1599.

Nagasaki, K., Kim, J.J., Tomaru, Y., Takao, Y., and Nagai, S. (2009). Isolation and characterization of a novel virus infecting Teleaulax amphioxeia (Cryptophyceae). Plankton Benthos Res. 4, 122-124.

Nagasaki, K., Shirai, Y., Takao, Y., Mizumoto, H., Nishida, K., and Tomaru, Y. (2005a). Comparison of genome sequences of single-stranded RNA viruses infecting the bivalve-killing dinoflagellate Heterocapsa circularisquama. Appl. Environ. Microbiol. 71, 8888-8894.

Nagasaki, K., Shirai, Y., Tomaru, Y., Nishida, K., and Pietrokovski, S. (2005b). Algal viruses with distinct intraspecies host specificities include identical intein elements. Appl. Environ. Microbiol. 71, 3599-3607.

Nagasaki, K., Tarutani, K., and Yamaguchi, M. (1999). Growth characteristics of Heterosigma akashiwo virus and its possible use as a microbiological agent for red tide control. Appl. Environ. Microbiol. 65, 898-902.

Nagasaki, K., Tomaru, Y., Katanozaka, N., Shirai, Y., Nishida, K., Itakura, S., and Yamaguchi, M. (2004). Isolation and characterization of a novel single-stranded RNA virus infecting the bloom-forming diatom Rhizosolenia setigera. Appl. Environ. Microbiol. 70, 704-711.
Nagasaki, K., Tomaru, Y., Takao, Y., Nishida, K., Shirai, Y., Suzuki, H., and Nagumo, T. (2005c). Previously unknown virus infects marine diatom. Appl. Environ. Microbiol. 71, 3528-3535.

Nagasaki, K., Tomaru, Y., Tarutani, K., Katanozaka, N., Yamanaka, S., Tanabe, H., and Yamaguchi, M. (2003). Growth characteristics and intraspecies host specificity of a large virus infecting the dinoflagellate Heterocapsa circularisquama. Appl. Environ. Microbiol. 69, 25802586.

Nagasaki, K., and Yamaguchi, M. (1997). Isolation of a virus infectious to the harmful bloom causing microalga Heterosigma akashiwo (Raphidophyceae). Aquat. Microb. Ecol. 13, 135-140.

Nagasaki, K., and Yamaguchi, M. (1998). Intra-species host specificity of $\mathrm{HaV}$ (Heterosigma akashiwo virus) clones. Aquat. Microb. Ecol. 14, 109-112.

Nissimov, J.I., Worthy, C.A., Rooks, P., Napier, J.A., Kimmance, S.A., Henn, M.R., Ogata, H., and Allen, M.J. (2011a). Draft genome sequence of the coccolithovirus EhV-84. Stand. Genomic Sci. 5, 1-11. https://doi. org/10.4056/sigs. 1884581 .

Nissimov, J.I., Worthy, C.A., Rooks, P., Napier, J.A., Kimmance, S.A., Henn, M.R., Ogata, H., and Allen, M.J. (2011b). Draft genome sequence of the Coccolithovirus Emiliania huxleyi virus 203. J. Virol. 85, 13468-13469. https://doi.org/10.1128/JVI.06440-11.

Nissimov, J.I., Worthy, C.A., Rooks, P., Napier, J.A., Kimmance, S.A., Henn, M.R., Ogata, H., and Allen, M.J. (2012a). Draft genome sequence of four coccolithoviruses: Emiliania huxleyi virus EhV-88, EhV201, EhV-207, and EhV-208. J. Virol. 86, 2896-2897. https://doi.org/10.1128/JVI.07046-11.

Nissimov, J.I., Worthy, C.A., Rooks, P., Napier, J.A., Kimmance, S.A., Henn, M.R., Ogata, H., and Allen, M.J. (2012b). Draft genome sequence of the coccolithovirus Emiliania huxleyi virus 202. J. Virol. 86, 2380-2381. https://doi.org/10.1128/JVI.06863-11.

Ogata, H., Ray, J., Toyoda, K., Sandaa, R.A., Nagasaki, K., Bratbak, G., and Claverie, J.M. (2011). Two new subfamilies of DNA mismatch repair proteins (MutS) specifically abundant in the marine environment. ISME J. 5, 1143-1151. https://doi.org/10.1038/ ismej.2010.210.

Ogata, H., Toyoda, K., Tomaru, Y., Nakayama, N., Shirai, Y., Claverie, J.M., and Nagasaki, K. (2009). Remarkable sequence similarity between the dinoflagellateinfecting marine girus and the terrestrial pathogen African swine fever virus. Virol. J. 6, 178. https://doi. org/10.1186/1743-422X-6-178.

Pagarete, A., Grébert, T., Stepanova, O., Sandaa, R.A., and Bratbak, G. (2015). Tsv-N1: a novel DNA algal virus that infects Tetraselmis striata. Viruses 7, 3937-3953. https://doi.org/10.3390/v7072806.

Pagarete, A., Kusonmano, K., Petersen, K., Kimmance, S.A., Martínez Martínez, J., Wilson, W.H., Hehemann, J.H., Allen, M.J., and Sandaa, R.A. (2014). Dip in the gene pool: metagenomic survey of natural coccolithovirus communities. Virology 466-467, 129-137. https://doi. org/10.1016/j.virol.2014.05.020.

Pagarete, A., Lanzén, A., Puntervoll, P., Sandaa, R.A., Larsen, A., Larsen, J.B., Allen, M.J., and Bratbak, G. (2013). Genomic sequence and analysis of EhV-99B1, a new 
coccolithovirus from the Norwegian fjords. Intervirology 56, 60-66. https://doi.org/10.1159/000341611.

Park, Y., Lee, K., Lee, Y.S., Kim, S.W., and Choi, T.J. (2011). Detection of diverse marine algal viruses in the South Sea regions of Korea by PCR amplification of the DNA polymerase and major capsid protein genes. Virus Res. 159, 43-50. https://doi.org/10.1016/j. virusres.2011.04.024.

Pringle, C.R. (1998). Virus taxonomy - San Diego 1998. Arch. Virol. 143, 1449-1459.

Raoult, D., Audic, S., Robert, C., Abergel, C., Renesto, P., Ogata, H., La Scola, B., Suzan, M., and Claverie, J.M. (2004). The 1.2-megabase genome sequence of Mimivirus. Science 306, 1344-1350.

Reisser, W., Becker, B., and Klein, T. (1986). Studies on ultrastructure and host range of a Chlorella attacking virus. Protoplasma 135, 162-5.

Reisser, W., Burbank, D.E., Meints, R.H., Becker, B., and Vanetten, J.L. (1991). Viruses distinguish symbiotic Chlorella spp. of Paramecium bursaria. Endocytobiosis Cell Res. 7, 245-251.

Reisser, W., Burbank, D.E., Meints, S.M., Meints, R.H., Becker, B., and Van Etten, J.L. (1988). A comparison of viruses infecting two different Chlorella-like green algae. Virology 167, 143-149.

Rosario, K., Nilsson, C., Lim, Y.W., Ruan, Y., and Breitbart, M. (2009). Metagenomic analysis of viruses in reclaimed water. Environ. Microbiol. 11, 2806-2820. https://doi. org/10.1111/j.1462-2920.2009.01964.x.

Rowe, J.M., Fabre, M.F., Gobena, D., Wilson, W.H., and Wilhelm, S.W. (2011). Application of the major capsid protein as a marker of the phylogenetic diversity of Emiliania huxleyi viruses. FEMS Microbiol. Ecol. 76, 373-380. https://doi.org/10.1111/j.15746941.2011.01055.x.

Rozon, R.M., and Short, S.M. (2013). Complex seasonality observed amongst diverse phytoplankton viruses in the Bay of Quinte, an embayment of Lake Ontario. Freshwater Biol. 58, 2648-2663.

Rusch, D.B., Halpern, A.L., Sutton, G., Heidelberg, K.B., Williamson, S., Yooseph, S., Wu, D., Eisen, J.A., Hoffman, J.M., Remington, K., et al. (2007). The Sorcerer II Global Ocean Sampling expedition: northwest Atlantic through eastern tropical Pacific. PLOS Biol. 5, e77.

Sahlsten, E. (1998). Seasonal abundance in SkagerrakKattegat coastal waters and host specificity of viruses infecting the marine photosynthetic flagellate Micromonas pusilla. Aquat. Microb. Ecol. 16, 103-108.

Sandaa, R.A., Heldal, M., Castberg, T., Thyrhaug, R., and Bratbak, G. (2001). Isolation and characterization of two viruses with large genome size infecting Chrysochromulina ericina (Prymnesiophyceae) and Pyramimonas orientalis (Prasinophyceae). Virology 290, 272-280.

Santini, S., Jeudy, S., Bartoli, J., Poirot, O., Lescot, M., Abergel, C., Barbe, V., Wommack, K.E., Noordeloos, A.A., Brussaard, C.P., et al. (2013). Genome of Phaeocystis globosa virus PgV-16T highlights the common ancestry of the largest known DNA viruses infecting eukaryotes. Proc. Natl. Acad. Sci. U.S.A. 110, 10800-10805. https:// doi.org/10.1073/pnas.1303251110.

Schroeder, D.C., Oke, J., Malin, G., and Wilson, W.H. (2002). Coccolithovirus (Phycodnaviridae): characterisation of a new large dsDNA algal virus that infects Emiliania huxleyi. Arch. Virol. 147, 1685-1698.

Schroeder, D.C., Park, Y., Yoon, H.M., Lee, Y.S., Kang, S.W., Meints, R.H., Ivey, R.G., and Choi, T.J. (2009). Genomic analysis of the smallest giant virus - Feldmannia sp. virus 158. Virology 384, 223-232. https://doi.org/10.1016/j. virol.2008.10.040.

Shirai, Y., Takao, Y., Mizumoto, H., Tomaru, Y., Honda, D., and Magasaki, K. (2006). Genomic and phylogenetic analysis of a single-stranded RNA virus infecting Rhizosolenia setigera (Stramenopiles: Bacillariophyceae). J. Mar. Biol. Assoc. U.K. 86, 475-483.

Shirai, Y., Tomaru, Y., Takao, Y., Suzuki, H., Nagumo, T., and Nagasaki, K. (2008). Isolation and characterization of a single-stranded RNA virus infecting the marine planktonic diatom Chaetoceros tenuissimus Meunier. Appl. Environ. Microbiol. 74, 4022-4027. https://doi. org/10.1128/AEM.00509-08.

Short, S.M. (2012). The ecology of viruses that infect eukaryotic algae. Environ. Microbiol. 14, 2253-2271. https://doi.org/10.1111/j.1462-2920.2012.02706.x.

Short, S.M., Rusanova, O., and Staniewski, M.A. (2011). Novel phycodnavirus genes amplified from Canadian freshwater environments. Aquat. Microb. Ecol. 63, 61-67.

Short, S.M., and Short, C.M. (2008). Diversity of algal viruses in various North American freshwater environments. Aquat. Microb. Ecol. 51, 13-21.

Short, S.M., and Suttle, C.A. (2002). Sequence analysis of marine virus communities reveals that groups of related algal viruses are widely distributed in nature. Appl. Environ. Microbiol. 68, 1290-1296.

Short, S.M., and Suttle, C.A. (2003). Temporal dynamics of natural communities of marine algal viruses and eukaryotes. Aquat. Microb. Ecol. 32, 107-119.

Slapeta, J., López-García, P., and Moreira, D. (2006). Global dispersal and ancient cryptic species in the smallest marine eukaryotes. Mol. Biol. Evol. 23, 23-29.

Steward, G.F., Culley, A.I., Mueller, J.A., Wood-Charlson, E.M., Belcaid, M., and Poisson, G. (2013). Are we missing half of the viruses in the ocean? ISME J. 7, 672-679. https://doi.org/10.1038/ismej.2012.121.

Steward, G.F., and Preston, C.M. (2011). Analysis of a viral metagenomic library from $200 \mathrm{~m}$ depth in Monterey Bay, California constructed by direct shotgun cloning. Virol. J. 8, 287. https://doi.org/10.1186/1743-422X-8-287.

Suttle, C.A. (2000). Ecological, evolutionary, and geochemical consequences of viral infection of cyanobacteria and eukaryotic algae. In Viral Ecology, Hurst, C.J. ed. (Academic Press, San Diego), pp. 247296.

Suttle, C.A., and Chan, A.M. (1995). Viruses infecting the marine Prymnesiophyte Chrysochromulina spp.: Isolation, preliminary characterization and natural abundance. Mar. Ecol. Prog. Ser. 118, 275-282.

Tai, V., Lawrence, J.E., Lang, A.S., Chan, A.M., Culley, A.I., and Suttle, C.A. (2003). Characterization of HaRNAV, a single-stranded RNA virus causing lysis of Heterosigma akashiwo (Raphidophyceae). J. Phycol. 39, 343-352.

Tarutani, K., Nagasaki, K., Itakura, S., and Yamaguchi, M. (2001). Isolation of a virus infecting the novel shellfishkilling dinoflagellate Heterocapsa circularisquama. Aquat. Microb. Ecol. 23, 103-111. 
Tarutani, K., Nagasaki, K., and Yamaguchi, M. (2000). Viral impacts on total abundance and clonal composition of the harmful bloom-forming phytoplankton Heterosigma akashiwo. Appl. Environ. Microbiol. 66, 4916-4920.

Tomaru, Y., Hata, N., Masuda, T., Tsuji, M., Igata, K., Masuda, Y., Yamatogi, T., Sakaguchi, M., and Nagasaki, K. (2007). Ecological dynamics of the bivalve-killing dinoflagellate Heterocapsa circularisquama and its infectious viruses in different locations of western Japan. Environ. Microbiol. 9, 1376-1383.

Tomaru, Y., Katanozaka, N., Nishida, K., Shirai, Y., Tarutani, K., Yamaguchi, M., and Nagasaki, K. (2004a). Isolation and characterization of two distinct types of HcRNAV, a single-stranded RNA virus infecting the bivalve-killing microalga Heterocapsa circularisquama. Aquat. Microb. Ecol. 34, 207-218.

Tomaru, Y., Mizumoto, H., Takao, Y., and Nagasaki, K. (2009a). Co-occurrence of DNA and RNA viruses infecting the bloom-forming dinoflagellate Heterocapsa circularisquama, on the Japan Coast. Plankton Benthos Res. 4, 129-134.

Tomaru, Y., and Nagasaki, K. (2004). Widespread occurrence of viruses lytic to the bivalve-killing dinoflagellate Heterocapsa circularisquama in the Western coast of Japan. Plankton Biol. Ecol. 51, 1-6.

Tomaru, Y., Shirai, Y., and Nagasaki, K. (2008a). Ecology, physiology and genetics of a phycodnavirus infecting the noxious bloom-forming raphidophyte Heterosigma akashiwo. Fish. Sci. 74, 701-711.

Tomaru, Y., Shirai, Y., Suzuki, H., Nagumo, T., and Nagasaki, K. (2008b). Isolation and characterization of a new single-stranded DNA virus infecting the cosmopolitan marine diatom Chaetoceros debilis. Aquat. Microb. Ecol. 50, 103-112.

Tomaru, Y., Shirai, Y., Toyoda, K., and Nagasaki, K. (2011a). Isolation and characterisation of a single-stranded DNA virus infecting the marine planktonic diatom Chaetoceros tenuissimus. Aquat. Microb. Ecol. 64, 175-184.

Tomaru, Y., Takao, Y., Suzuki, H., Nagumo, T., Koike, K., and Nagasaki, K. (2011b). Isolation and characterization of a single-stranded DNA virus infecting Chaetoceros lorenzianus Grunow. Appl. Environ. Microbiol. 77, 5285-5293. https://doi.org/10.1128/AEM.00202-11.

Tomaru, Y., Takao, Y., Suzuki, H., Nagumo, T., and Nagasaki, K. (2009b). Isolation and characterization of a singlestranded RNA virus infecting the bloom-forming diatom Chaetoceros socialis. Appl. Environ. Microbiol. 75, 2375-2381. https://doi.org/10.1128/AEM.0258008.

Tomaru, Y., Tarutani, K., Yamaguchi, M., and Nagasaki, K. (2004b). Quantitative and qualitative impacts of viral infection on a Heterosigma akashiwo (Raphidophyceae) bloom in Hiroshima Bay, Japan. Aquat. Microb. Ecol. 34, 227-238.

Tomaru, Y., Toyoda, K., Kimura, K., Hata, N., Yoshida, M., and Nagasaki, K. (2012). First evidence for the existence of pennate diatom viruses. ISME J. 6, 1445-1448. https://doi.org/10.1038/ismej.2011.207.

Tomaru, Y., Toyoda, K., Kimura, K., Takao, Y., Sakurada, K., Nakayama, N., and Nagasaki, K. (2013a). Isolation and characterization of a single-stranded RNA virus that infects the marine planktonic diatom Chaetoceros sp (SS08-C03). Phycol. Res. 61, 27-36.
Tomaru, Y., Toyoda, K., Suzuki, H., Nagumo, T., Kimura, K., and Takao, Y. (2013b). New single-stranded DNA virus with a unique genomic structure that infects marine diatom Chaetoceros setoensis. Sci. Rep. 3, 3337. https:// doi.org/10.1038/srep03337.

Toyoda, K., Kimura, K., Hata, N., Nakayama, N., Nagasaki, N., and Tomaru, Y. (2012). Isolation and characterization of a single-stranded DNA virus infecting the marine planktonic diatom Chaetoceros sp. (Strain Tg07-C28). Plankton Benthos Res. 7, 20-28.

Van Etten, J.L., Burbank, D.E., Schuster, A.M., and Meints, R.H. (1985a). Lytic viruses infecting a Chlorella-like alga. Virology 140, 135-143.

Van Etten, J.L., Burbank, D.E., Xia, Y., and Meints, R.H. (1983). Growth cycle of a virus, PBCV-1, that infects Chlorella-like algae. Virology 126, 117-25.

Van Etten, J.L., Graves, M.V., Müller, D.G., Boland, W., and Delaroque, N. (2002). Phycodnaviridae - large DNA algal viruses. Arch. Virol. 147, 1479-1516. https://doi. org/10.1007/s00705-002-0822-6.

Van Etten, J.L., and Meints, R.H. (1999). Giant viruses infecting algae. Annu. Rev. Microbiol. 53, 447-494. https://doi.org/10.1146/annurev.micro.53.1.447.

Van Etten, J.L., Meints, R.H., Burbank, D.E., Kuczmarski, D., Cuppels, D.A., and Lane, L.C. (1981). Isolation and characterization of a virus from the intracellular greenalga symbiotic with Hydra Viridis. Virology 113, 704-11.

Van Etten, J.L., Meints, R.H., Kuczmarski, D., Burbank, D.E., and Lee, K. (1982). Viruses of symbiotic Chlorellalike algae isolated from Paramecium bursaria and Hydra viridis. Proc. Natl. Acad. Sci. U.S.A. 79, 3867-3871.

Van Etten, J.L., Van Etten, C.H., Johnson, J.K., and Burbank, D.E. (1985b). A survey for viruses from fresh water that infect a eucaryotic chlorella-like green alga. Appl. Environ. Microbiol. 49, 1326-1328.

Venter, J.C., Remington, K., Heidelberg, J.F., Halpern, A.L., Rusch, D., Eisen, J.A., Wu, D., Paulsen, I., Nelson, K.E., Nelson, W., et al. (2004). Environmental genome shotgun sequencing of the Sargasso Sea. Science 304, 66-74. https://doi.org/10.1126/science.1093857.

Vega Thurber, R.L., Barott, K.L., Hall, D., Liu, H., RodriguezMueller, B., Desnues, C., Edwards, R.A., Haynes, M., Angly, F.E., Wegley, L., et al. (2008). Metagenomic analysis indicates that stressors induce production of herpes-like viruses in the coral Porites compressa. Proc. Natl. Acad. Sci. U.S.A. 105, 18413-18418. https://doi. org/10.1073/pnas.0808985105.

Waters, R.E., and Chan, A.T. (1982). Micromonas pusilla virus: the virus growth cycle and associated physiological events within the host-cells; host range mutation. J. Gen. Virol. 63, 199-206.

Wegley, L., Edwards, R., Rodriguez-Brito, B., Liu, H., and Rohwer, F. (2007). Metagenomic analysis of the microbial community associated with the coral Porites astreoides. Environ. Microbiol. 9, 2707-2719.

Westbroek, P., Brown, C.W., Vanbleijswijk, J., Brownlee, C., Brummer, G.J., Conte, M., Egge, J., Fernandez, E., Jordan, R., Knappertsbusch, M., et al. (1993). A model system approach to biological climate forcing: the example of Emiliania huxleyi. Glob. Planet Change 8, 27-46.

Weynberg, K.D., Allen, M.J., Ashelford, K., Scanlan, D.J., and Wilson, W.H. (2009). From small hosts come big viruses: the complete genome of a second Ostreococcus 
tauri virus, OtV-1. Environ. Microbiol. 11, 2821-2839. https://doi.org/10.1111/j.1462-2920.2009.01991.x.

Williamson, S.J., Rusch, D.B., Yooseph, S., Halpern, A.L., Heidelberg, K.B., Glass, J.I., Andrews-Pfannkoch, C., Fadrosh, D., Miller, C.S., Sutton, G., et al. (2008). The Sorcerer II Global Ocean Sampling Expedition: metagenomic characterization of viruses within aquatic microbial samples. PLOS ONE 3, e1456. https://doi. org/10.1371/journal.pone.0001456.

Wilson, W.H., Francis, I., Ryan, K., and Davy, S.K. (2001) Temperature induction of viruses in symbiotic dinoflagellates. Aquat. Microb. Ecol. 25, 99-102.

Wilson, W.H., Gilg, I.C., Duarte, A., and Ogata, H. (2014). Development of DNA mismatch repair gene, MutS, as a diagnostic marker for detection and phylogenetic analysis of algal Megaviruses. Virology 466-467, 123-128. https://doi.org/10.1016/j.virol.2014.07.001.

Wilson, W.H., Schroeder, D.C., Allen, M.J., Holden, M.T., Parkhill, J., Barrell, B.G., Churcher, C., Hamlin, N., Mungall, K., Norbertczak, H., et al. (2005). Complete genome sequence and lytic phase transcription profile of a Coccolithovirus. Science 309, 1090-1092.

Wilson, W.H., Schroeder, D.C., Ho, J., and Canty, M. (2006). Phylogenetic analysis of PgV-102P, a new virus from the English Channel that infects Phaeocystis globosa. J. Mar. Biol. Assoc. U. K. 86, 485-490.

Wilson, W.H., Tarran, G.A., Schroeder, D., Cox, M., Oke, J., and Malin, G. (2002). Isolation of viruses responsible for the demise of an Emiliania huxleyi bloom in the English Channel. J. Mar. Biol. Assoc. U. K. 82, 369-377.

Wilson, W.H., Van Etten, J.L., and Allen, M.J. (2009). The Phycodnaviridae: the story of how tiny giants rule the world. In Lesser known large dsDNA viruses, pp. 1-42.

Yamada, T., Onimatsu, H., and Van Etten, J.L. (2006). Chlorella viruses. Adv. Virus Res. 66, 293-336.

Yau, S., Lauro, F.M., DeMaere, M.Z., Brown, M.V., Thomas, T., Raftery, M.J., Andrews-Pfannkoch, C., Lewis, M., Hoffman, J.M., Gibson, J.A., et al. (2011). Virophage control of antarctic algal host-virus dynamics. Proc. Natl. Acad. Sci. U.S.A. 108, 6163-6168. https://doi. org/10.1073/pnas.1018221108.

Yoon, H.S., Hackett, J.D., Ciniglia, C., Pinto, G., and Bhattacharya, D. (2004). A molecular timeline for the origin of photosynthetic eukaryotes. Mol. Biol. Evol. 21, 809-818. https://doi.org/10.1093/molbev/msh075.

Yoshida-Takashima, Y., Yoshida, M., Ogata, H., Nagasaki, K., Hiroishi, S., and Yoshida, T. (2012). Cyanophage infection in the bloom-forming cyanobacteria Microcystis aeruginosa in surface freshwater. Microbes Environ. 27, 350-355.

Zhang, W., Zhou, J., Liu, T., Yu, Y., Pan, Y., Yan, S., and Wang, Y. (2015). Four novel algal virus genomes discovered from Yellowstone Lake metagenomes. Sci. Rep. 5, 15131. https://doi.org/10.1038/srep15131.

Zhong, X., and Jacquet, S. (2014). Contrasting diversity of phycodnavirus signature genes in two large and deep western European lakes. Environ. Microbiol. 16, 759-773. https://doi.org/10.1111/1462-2920.12201.

Zhou, J., Sun, D., Childers, A., McDermott, T.R., Wang, Y., and Liles, M.R. (2015). Three novel virophage genomes discovered from Yellowstone Lake metagenomes. J. Virol. 89, 1278-1285. https://doi.org/10.1128/ JVI.03039-14.

Zhou, J., Zhang, W., Yan, S., Xiao, J., Zhang, Y., Li, B., Pan, Y., and Wang, Y. (2013). Diversity of virophages in metagenomic data sets. J. Virol. 87, 4225-4236. https:// doi.org/10.1128/JVI.03398-12.

Zingone, A., Natale, F., Biffali, E., Borra, M., Forlani, G., and Sarno, D. (2006). Diversity in morphology, infectivity, molecular characteristics and induced host resistance between two viruses infecting Micromonas pusilla. Aquat. Microb. Ecol. 45, 1-14.

Zingone, A., Sarno, D., and Forlani, G. (1999). Seasonal dynamics in the abundance of Micromonas pusilla (Prasinophyceae) and its viruses in the Gulf of Naples (Mediterranean Sea). J. Plankton Res. 21, 2143-2159. 
